Prepared in cooperation with Blue Water Baltimore

\title{
Factors Affecting Long-Term Trends in Surface- Water Quality in the Gwynns Falls Watershed, Baltimore City and County, Maryland, 1998-2016
}

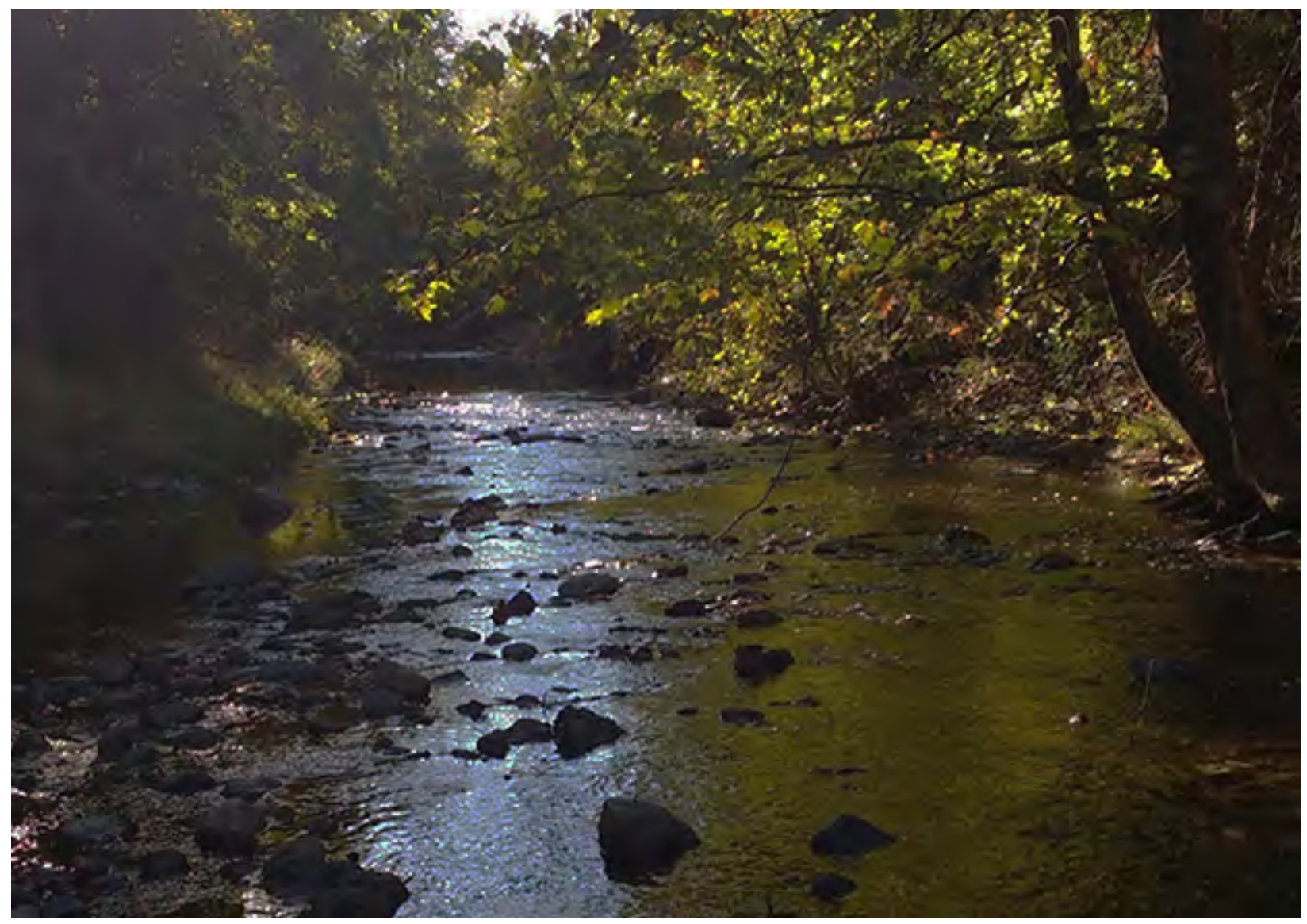

Open-File Report 2018-1038

U.S. Department of the Interior U.S. Geological Survey 
Cover. Blue Water Baltimore monitoring station in the main stem of the Gwynns Falls near the corner of Owings Mills Blvd. and Crondall Lane. (Photograph by Alice Volpitta, Blue Water Baltimore) 


\section{Factors Affecting Long-Term Trends in Surface-Water Quality in the Gwynns Falls Watershed, Baltimore City and County, Maryland, 1998-2016}

By Emily H. Majcher, Ellen L. Woytowitz, Alexander J. Reisinger, and Peter M. Groffman

Prepared in cooperation with Blue Water Baltimore

Open-File Report 2018-1038 


\title{
U.S. Department of the Interior \\ RYAN K. ZINKE, Secretary
}

\section{U.S. Geological Survey William H. Werkheiser, Deputy Director exercising the authority of the Director}

\author{
U.S. Geological Survey, Reston, Virginia: 2018
}

For more information on the USGS - the Federal source for science about the Earth, its natural and living resources, natural hazards, and the environment-visit https://www.usgs.gov or call 1-888-ASK-USGS.

For an overview of USGS information products, including maps, imagery, and publications, visit https://store.usgs.gov.

Any use of trade, firm, or product names is for descriptive purposes only and does not imply endorsement by the U.S. Government.

Although this information product, for the most part, is in the public domain, it also may contain copyrighted materials as noted in the text. Permission to reproduce copyrighted items must be secured from the copyright owner.

Suggested citation:

Majcher, E.H., Woytowitz, E.L., Reisinger, A.J., and Groffman, P.M., 2018, Factors affecting long-term trends in surface-water quality in the Gwynns Falls watershed, Baltimore City and County, Maryland, 1998-2016: U.S. Geological Survey Open-File Report 2018-1038, 27 p., https://doi.org/10.3133/ofr20181038.

ISSN 2331-1258 (online) 


\section{Acknowledgments}

The authors wish to thank Lynn Heller of the Abell Foundation, as well as the Chesapeake Bay Trust Chesapeake Conservation Corps program and the leadership of the Baltimore Ecosystem Study for project funding and in-kind project support. The authors thank David Flores (Center for Progressive Reform, formerly of Blue Water Baltimore) for insights and project development assistance, and Alice Volpitta and Angela Haren of Blue Water Baltimore for their assistance. Thanks to the members of the Baltimore Urban Waters Partnership, Actionable Science workgroup, for input on prioritization, data sharing, and project feedback. 



\section{Contents}

Acknowledgments ……...................................................................................................................

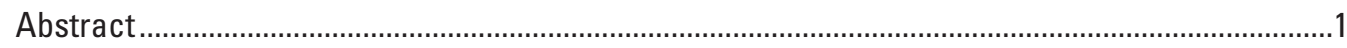

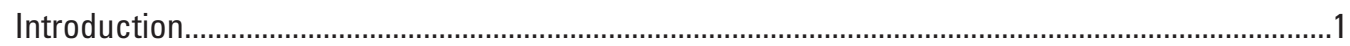

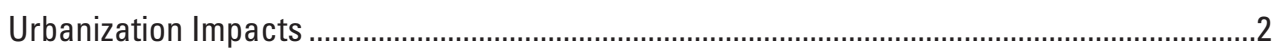

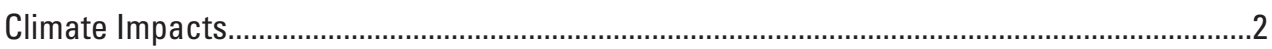

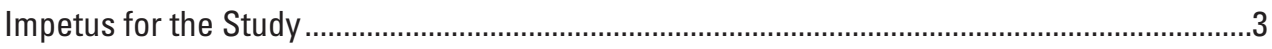

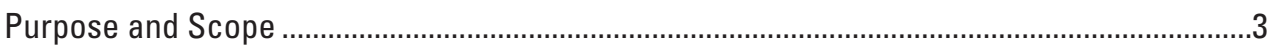

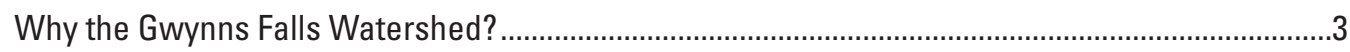

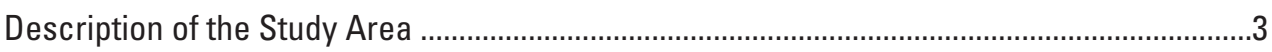

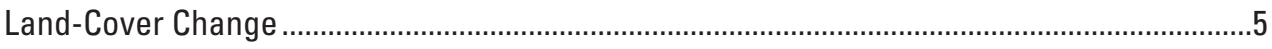

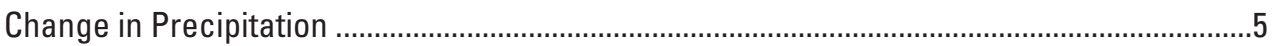

Is the Water Quality of the Gwynns Falls Watershed Changing?

Compilation of Data and Estimates of Water-Quality Trends ...................................................11

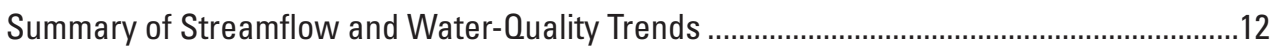

What Factors are Affecting Water-Quality Trends in the Gwynns Falls?......................................17

Evaluating Relations between Water Quality and Potential Factors of Influence...................17

Aging Gray Infrastructure and the Influence of Sanitary Sewer Overflows ...........................18

Implementation of Green Infrastructure and Effects of Best Management Practices...........23

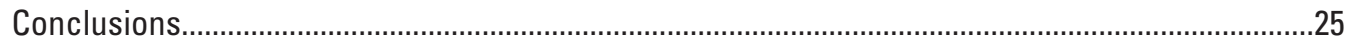

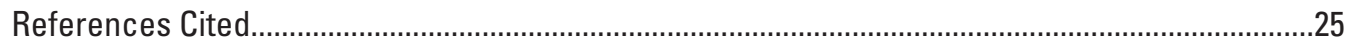

\section{Figures}

1. Map showing location of Gwynns Falls watershed and subwatersheds, and Baltimore Ecosystem Study Sites, Baltimore County and Baltimore City, Maryland ........4

2. Graph showing developed land cover and change in land cover, Gwynns Falls subwatersheds, Baltimore County and Baltimore City, Maryland, 2001-11

3. Graph showing annual precipitation and annual count of runoff producing storms, Baltimore Washington International Airport meteorological station, Maryland, water years 1999-2016.

4. Graphs showing trends in seasonal precipitation, water years 1999-2016, Baltimore Washington International Airport meteorological station, Maryland: $A$, spring, $B$, summer, $C$, autumn, and $D$, winter ...........................................................

5. Graphs showing trends in seasonal runoff producing storms, water years 1999-2016, Baltimore Washington International Airport meteorological station, Maryland: $A$, spring, $B$, summer, $C$, autumn, and $D$, winter ..

6. Graphs showing trends in contribution of seasonal runoff producing storms compared to total annual storms, water years 1999-2016, Baltimore Washington International Airport meteorological station, Maryland: $A$, spring, $B$, summer, $C$, autumn, and $D$, winter

7. Graph showing annual mean surface-water discharge, Baltimore Ecosystem Study sites, Baltimore County and Baltimore City, Maryland, water years 1999-2013. 
8. Graphs showing trends in $A$ and $C$, loads and $B$ and $D$, flow-weighted concentrations of nitrate (as nitrogen) and total nitrogen, Gwynns Falls Carroll Park subwatershed,

Maryland, water years 1999-2013.

9. Graphs showing trends in $A$ and $C$, loads and $B$ and $D$, flow-weighted concentrations of phosphate (as phosphorus) and total phosphorus, Gwynns Falls Carroll Park subwatershed, Maryland, water years 1999-2013

10. Graphs showing significant relation of median sanitary sewer overflow volume to $A$, annual nitrate (as nitrogen) load, and $B$, annual total coliform bacteria load, Gwynns Falls Carroll Park subwatershed, Maryland, water years 1999-2013

11. Graphs showing relations of mean total sanitary sewer overflow duration (mean) to $A$, annual nitrate (as nitrogen) load, $B$, annual phosphate (as phosphorus) load, $C$, total nitrogen load, and $D$, total phosphorus load, Gwynns Falls Carroll Park subwatershed, water years 1999-2013

12. Graphs showing significant and moderately significant relations of cumulative best management practices (drainage area) to $A$, annual phosphate (as phosphorus) load, $B$, total phosphorus load, $C$, annual phosphate (as phosphorus) flow-weighted concentration, and $D$, annual total phosphorus flow-weighted concentration, Gwynns Falls Carroll Park subwatershed, Maryland, water years 1999-2013

\section{Tables}

1. Summary of water-quality constituents, data sources, and dates of data collection.

2. Summary of water-quality constituent trends in Gwynns Falls subwatersheds, Maryland, water years 1999-2013.

3. Summary of compiled factors of influence, data sources, and date ranges for factors.

4. Summary of relations between water-quality constituents and factors of influence. 


\section{Conversion Factors}

International System of Units to U.S. customary units

\begin{tabular}{|c|c|c|}
\hline Multiply & By & To obtain \\
\hline \multicolumn{3}{|c|}{ Length } \\
\hline centimeter $(\mathrm{cm})$ & 0.3937 & inch (in.) \\
\hline millimeter $(\mathrm{mm})$ & 0.03937 & inch (in.) \\
\hline meter $(\mathrm{m})$ & 3.281 & foot $(\mathrm{ft})$ \\
\hline kilometer $(\mathrm{km})$ & 0.6214 & mile (mi) \\
\hline meter $(\mathrm{m})$ & 1.094 & yard (yd) \\
\hline \multicolumn{3}{|c|}{ Area } \\
\hline square meter $\left(\mathrm{m}^{2}\right)$ & 0.0002471 & acre \\
\hline hectare (ha) & 2.471 & acre \\
\hline square kilometer $\left(\mathrm{km}^{2}\right)$ & 247.1 & acre \\
\hline square centimeter $\left(\mathrm{cm}^{2}\right)$ & 0.001076 & square foot $\left(\mathrm{ft}^{2}\right)$ \\
\hline square meter $\left(\mathrm{m}^{2}\right)$ & 10.76 & square foot $\left(\mathrm{ft}^{2}\right)$ \\
\hline square centimeter $\left(\mathrm{cm}^{2}\right)$ & 0.1550 & square inch $\left(\mathrm{ft}^{2}\right)$ \\
\hline square kilometer $\left(\mathrm{km}^{2}\right)$ & 0.3861 & square mile $\left(\mathrm{mi}^{2}\right)$ \\
\hline \multicolumn{3}{|c|}{ Volume } \\
\hline liter $(\mathrm{L})$ & 0.2642 & gallon (gal) \\
\hline cubic meter $\left(\mathrm{m}^{3}\right)$ & 264.2 & gallon (gal) \\
\hline cubic meter $\left(\mathrm{m}^{3}\right)$ & 35.31 & cubic foot $\left(\mathrm{ft}^{3}\right)$ \\
\hline cubic meter $\left(\mathrm{m}^{3}\right)$ & 1.308 & cubic yard $\left(\mathrm{yd}^{3}\right)$ \\
\hline cubic meter $\left(\mathrm{m}^{3}\right)$ & 0.0008107 & acre-foot (acre-ft) \\
\hline liter $(\mathrm{L})$ & 61.02 & cubic inch $\left(\right.$ in $\left.^{3}\right)$ \\
\hline \multicolumn{3}{|c|}{ Flow rate } \\
\hline liter per second $(\mathrm{L} / \mathrm{s})$ & 15.85 & gallon per minute (gal/min) \\
\hline \multicolumn{3}{|c|}{ Mass } \\
\hline $\operatorname{gram}(\mathrm{g})$ & 0.03527 & ounce, avoirdupois (oz) \\
\hline kilogram (kg) & 2.205 & pound avoirdupois (lb) \\
\hline metric ton & $2,204.6$ & pound avoirdupois (lb) \\
\hline
\end{tabular}

Temperature in degrees Celsius $\left({ }^{\circ} \mathrm{C}\right)$ may be converted to degrees Fahrenheit $\left({ }^{\circ} \mathrm{F}\right)$ as ${ }^{\circ} \mathrm{F}=\left(1.8 \times{ }^{\circ} \mathrm{C}\right)+32$.

Temperature in degrees Fahrenheit $\left({ }^{\circ} \mathrm{F}\right)$ may be converted to degrees Celsius $\left({ }^{\circ} \mathrm{C}\right)$ as

$$
{ }^{\circ} \mathrm{C}=\left({ }^{\circ} \mathrm{F}-32\right) / 1.8 \text {. }
$$

Vertical coordinate information is referenced to the National Geodetic Vertical Datum of 1929 (NGVD 29).

Concentrations of chemical constituents in water are given in either milligrams per liter (mg/L) or kilograms per liter $(\mathrm{kg} / \mathrm{L})$. Concentrations of bacteria in water are given in most probable number per liter (MPN/L). 


\section{Abbreviations}

$\begin{array}{ll}\text { BARN } & \text { Baisman Run } \\ \text { BES } & \text { Baltimore Ecosystem Study } \\ \text { BMP } & \text { Best Management Practice } \\ \text { DEPS } & \text { Department of Environmental Protection and Sustainability } \\ \text { DPW } & \text { Department of Public Works } \\ \text { EPA } & \text { U.S. Environmental Protection Agency } \\ \text { FWC } & \text { Flow-weighted concentration } \\ \text { GFCP } & \text { Gwynns Falls Carroll Park } \\ \text { GFGB } & \text { Gwynns Falls Gwynnbrook } \\ \text { GFGL } & \text { Gwynns Falls Glyndon } \\ \text { GFVN } & \text { Gwynns Falls Villa Nova } \\ \text { LTER } & \text { Long Term Ecological Research } \\ \text { MDE } & \text { Maryland Department of Environment } \\ \text { MS4 } & \text { Municipal separate storm sewer system } \\ \text { POBR } & \text { Pond Branch } \\ \text { SSO } & \text { Sanitary Sewer Overflow } \\ \text { TMDL } & \text { Total Maximum Daily Load } \\ \text { USGS } & \text { U.S. Geological Survey } \\ & \end{array}$




\title{
Factors Affecting Long-Term Trends in Surface-Water Quality in the Gwynns Falls Watershed, Baltimore City and County, Maryland, 1998-2016
}

\author{
By Emily H. Majcher' ${ }^{1}$, Ellen L. Woytowitz ${ }^{2}$, Alexander J. Reisinger ${ }^{3}$, and Peter M. Groffman ${ }^{4}$
}

\section{Abstract}

Factors affecting water-quality trends in urban streams are not well understood, despite current regulatory requirements and considerable ongoing investments in gray and green infrastructure. To address this gap, long-term water-quality trends and factors affecting these trends were examined in the Gwynns Falls, Maryland, watershed during 1998-2016 in cooperation with Blue Water Baltimore. Data on water-quality constituents and potential factors of influence were obtained from multiple sources and compiled for analysis, with a focus on data collected as part of the National Science Foundation funded Long-Term Ecological Research project, the Baltimore Ecosystem Study.

Variability in climate (specifically, precipitation) and land cover can overwhelm actions taken to improve water quality and can present challenges for meeting regulatory goals. Analysis of land cover during 2001-11 in the Gwynns Falls watershed indicated minimal change during the study time frame; therefore, land-cover change is likely not a factor affecting trends in water quality. However, a modest increase in annual precipitation and a significant increase in winter precipitation were apparent in the region. A higher proportion of runoff producing storms was observed in the winter and a lower proportion in the summer, indicating that climate change may affect water quality in the watershed. The increase in precipitation was not reflected in annual or seasonal trends of streamflow in the watershed. Nonetheless, these precipitation changes may exacerbate the inflow and infiltration of water to gray infrastructure and reduce the effectiveness of green infrastructure.

For streamflow and most water-quality constituents examined, no discernable trends were noted over the timeframe examined. Despite the increases in precipitation,

\footnotetext{
${ }^{1}$ U.S. Geological Survey.

${ }^{2}$ Formerly U.S. Geological Survey.

${ }^{3}$ Formerly Cary Institute of Ecosystem Studies, currently University of Florida.

${ }^{4}$ City University of New York and Cary Institute of Ecosystem Studies.
}

no trends were observed for annual or seasonal discharge at the various sites within the study area. In some locations, nitrate, phosphate, and total nitrogen show downward trends, and total phosphorus and chloride show upward trends.

Sanitary sewer overflows (gray infrastructure) and best management practices (green infrastructure) were identified as factors affecting water-quality change. The duration of sanitary sewer overflows was positively correlated with annual loads of nutrients and bacteria, and the drainage area of best management practices was negatively correlated with annual loads of phosphate and sulfate. Results of the study indicate that continued investments in gray and green infrastructure are necessary for urban water-quality improvement. Although this outcome is not unexpected, long-term datasets such as the one used in this study, allow the effects of gray and green infrastructures to be quantified.

Results of this study have implications for the Gwynns Falls watershed and its residents and Baltimore City and County managers. Moreover, outcomes are relevant to other watersheds in the metropolitan region that do not have the same long-term dataset. Further, this study has established a framework for ongoing statistical analysis of primary factors affecting urban water-quality trends as regulatory programs mature.

\section{Introduction}

Human activities have dramatically altered the input of contaminants, especially nutrients, to coastal waters. In order to address the problem of eutrophication (a condition that results in decreased oxygen and increased algal blooms largely as a result of nutrient runoff), numerous studies have begun to investigate the factors that control nitrogen and phosphorus export from coastal watersheds, including the Chesapeake Bay watershed. These investigations are particularly important and challenging in urban and suburban watersheds. Urban and suburban land cover is increasing across the United States. For example, between 1990 and 2000, developed land increased in the Chesapeake Bay watershed by 61 percent (Jantz and others, 2005). 


\section{Urbanization Impacts}

Urbanization has complex effects on the behavior and overall impacts of nutrients in the landscape, resulting in loads of these nutrients entering waterways (Kaye and others, 2006; Wollheim and others, 2013). In addition to increasing inputs of contaminants from air pollution (Bettez and Groffman, 2013; Rao and others, 2014), fertilizers (Law and others, 2004), and sewage (Valiela and others, 1997), urbanization also affects the amount of nitrogen and phosphorus retained in the landscape by increasing runoff that results from increased impervious surfaces. Increasing impervious surface decreases the area in which runoff can naturally move into the soil and subsurface, which can prevent nitrogen from being cycled back into the environment or retained in the landscape. Further, increased runoff degrades streams and riparian areas, reducing the ability of these areas to function as retention "sinks" for nutrients in the watershed (Walsh and others, 2005). Stormwater control structures, including green infrastructure, temporarily hold, divert, and treat stormwater, resulting in more infiltration and thus retention of the nutrients in the soil (Bettez and Groffman, 2012).

Baltimore, Maryland, may be unique because, following a large fire in 1904, the stormwater sewer system was separated from the sanitary sewer system. Although this reduces problems with "combined sewer overflows," it results in direct discharge of stormwater runoff to streams and receiving waters that increases with urban and suburban development and impervious surface. As a result, the only contamination source that is considered to be increasing in the Chesapeake Bay region is stormwater runoff (Chesapeake Bay Foundation, 2014). In Maryland, all large municipalities are required to obtain and comply with municipal separate storm sewer system (MS4) permits from Maryland Department of the Environment (MDE) to control stormwater contamination in the form of runoff to the "maximum extent practicable." Jurisdictions are required by their permits to mitigate stormwater contamination by implementing best management practices (BMPs) and watershed restoration. Further, goals have been set to reduce the input of different contaminants, including nutrients, to waterways through the establishment of total maximum daily loads (TMDL)s, which were established to help communities comply with Maryland water-quality standards for waterways by using BMPs. BMPs are applied broadly (in the case of the Chesapeake Bay TMDL for nutrients and sediment) and locally to individual impaired waterways, such as the Gwynns Falls, which is considered impaired because of the presence of fecal bacteria and chlordane (a pesticide), in addition to sediment and nutrients. Examples of BMPs for TMDL compliance include bioretention facilities, constructed wetlands, green roofs, infiltration basins, rain gardens, and rain barrels. These measures, implemented by jurisdictions with the help of non-governmental organizations and other community groups, are variable in their effectiveness and cost. In Maryland, BMPs tend to be less cost effective in urban areas than in non-urban areas (Greg Busch,
Maryland Department of Environment, written commun., November 2013). An assessment of the cost effectiveness of BMPs in the James River Basin (Virginia) indicates that detection and elimination of illegal connections to the stormwater discharge network (commonly called Illicit Discharge Detection and Elimination), and use of pet waste management and stream restoration practices, resulted in the greatest reductions in nutrients and sediment (Center for Watershed Protection, 2013).

The aging infrastructure of the Baltimore City and County sanitary sewer system has resulted in numerous unregulated discharges of untreated sewage to waterways (also called sanitary sewer overflows, or SSOs). Aging infrastructure is not unique to Baltimore. It is a common problem in the United States as a whole and can be considered a public health concern (American Society of Civil Engineers, 2017). SSOs occur when the capacity of the pipes is exceeded because of infiltration and inflow as a result of cracks and leaks, or when a blockage occurs as a result of the presence of foreign objects in the piping system (for example, fats, oils, grease, and wipes). In order to improve the aging infrastructure and reduce SSOs, Baltimore City (U.S. Department of Justice and others, 2002, 2017) and Baltimore County (U.S. Department of Justice and others, 2005) entered into agreements with the U.S. Environmental Protection Agency and Maryland Department of Environment. These Consent Decree agreements require large capital investments estimated to be about $\$ 2$ billion once completed (Baltimore City Department of Public Works, presentation from public meeting to discuss sewer Consent Decree, written commun., June 2016) to meet mandated goals.

\section{Climate Impacts}

Along with urbanization, climate is expected to change for large parts of the United States over the 21st century. Although the changes are predicted to vary by region with high uncertainty in the long term, it is expected that the variability and incidence of climatic extremes, such as heavy precipitation [greater than 5 centimeters $(\mathrm{cm})$ in less than 48 hours], will increase (Walsh and others, 2014). Northern areas, especially the Northeastern United States, are expected to experience increases in precipitation, as well as warmer conditions during the winter months, resulting in more precipitation falling as rain and less as snow, which will decrease the magnitude of snowmelt events but increase the frequency of moderate runoff events (Hayhoe and others, 2007). Even modest increases in rain events can have substantial effects on urban streams because scouring floods can occur in response to small rain events $(<0.75 \mathrm{~cm}$; Murdock and others, 2004; Vietz and others, 2016) and subsequently alter ecosystem functions within urban streams (Reisinger and others, 2017). Numerous studies have shown that increased precipitation results in higher input of nitrogen to receiving waters and less natural uptake of nitrogen in the watershed (Morse and Wollheim, 2014; Kaushal and others, 2008; Chiwa and others, 2010). 


\section{Impetus for the Study}

Given the changing land use and precipitation, coupled with the rapid implementation of BMPs and ongoing sewer repairs, there is a critical need to determine whether the investments have produced the desired improvements in water quality. It is also important to have an understanding of the primary factors affecting water-quality trends. For example, it is important to understand whether water quality has improved not as a result of management interventions alone, but because dry weather has reduced the runoff of pollutants from land to water. Alternatively, long-term water-quality improvements may go undetected, not because interventions are ineffective, but because other factors such as continuing land-use change or increases in precipitation have overwhelmed the positive effects of these interventions. A wide variety of stakeholders, such as the general public, neighborhood groups, municipal authorities, and regulatory agencies, are interested and invested in the results of these analyses, which are complex and require a long-term record. This project, initiated in 2016 in cooperation with Blue Water Baltimore, started to investigate these questions.

\section{Purpose and Scope}

The purpose of this report is to provide the preliminary results of a retrospective analysis of water quality and the factors affecting water quality in the Gwynns Falls watershed of Baltimore County and Baltimore City, Maryland, between 1998 and 2016. Methods are presented for compilation of water-quality data constituents, as well as computation of loads from constituent concentration and streamflow (data presented elsewhere, Woytowitz and others, 2018). Methods for and results of analysis of relations between loads [and flow-weighted concentrations (FWC)] and factors affecting water quality are presented. Results of this study have implications for the Gwynns Falls watershed and receiving waters, the residents, and city and county managers. Outcomes are relevant to other watersheds in the metropolitan region that do not have the same long-term dataset. In summary, the purpose of this report is to improve the understanding of the following questions.

1. How have concentrations and loads of various constituents in the Gwynns Falls watershed changed over the past 15 years?

2. What are the dominant factors that have contributed to these changes, regionally and locally?

\section{Why the Gwynns Falls Watershed?}

A 2014 monitoring-focused workshop with stakeholders in the Greater Baltimore region identified the need to further understand factors affecting water-quality change, particularly at the watershed scale (Majcher, 2014). One reason this knowledge gap exists is that these investigations require a long-term dataset with monitoring performed at a high frequency, which is rather uncommon. The Gwynns Falls watershed was selected largely because it is the main study watershed of the U.S. National Science Foundation funded Baltimore Ecosystem Study (BES) urban Long-Term Ecological Research (LTER) project, which has conducted weekly sampling coupled with continuous streamflow measurement [in collaboration with the U.S. Geological Survey (USGS)] at several sites since 1998. The BES project is designed to answer basic science questions; however, the long-term data provide an opportunity to broaden the use of the basic scientific research by performing additional studies to inform local managers and residents.

The data collected by BES LTER and other organizations in the Gwynns Falls watershed, including Baltimore City Department of Public Works, Baltimore County Department of Environmental Protection and Sustainability, and the USGS, provide the long-term record to make these analyses possible. Further, Gwynns Falls provides a unique, intermediate size drainage area, in which factors that affect water-quality change can be examined. Typically, monitoring is required and conducted at a local scale (for example, BMP level evaluation per MS4 permit requirements) and at a broader Chesapeake Bay watershed scale (Moyer and Bloomquist, 2016). The intermediate scale represented by the Gwynns Falls study area allows us to focus on a larger drainage area than an individual BMP, while still being able to isolate specific management actions within the watershed.

The watershed is further described in this section, and its associated land use and climate variation over time are described. The effects of land cover and climate change in relation to the improvement or decline of water quality in the Gwynns Falls stream is presented.

\section{Description of the Study Area}

The Gwynns Falls watershed encompasses 24 percent of the Baltimore City and 7 percent of Baltimore County, and contributes 21 percent of the total water input and 25 percent of the contaminant load to the Baltimore Inner Harbor (MDE, 2010). The 170.67 square kilometer (65.9-square mile) watershed extends from rural/suburban Baltimore County to the center of Baltimore City (fig. 1) and drains into the Middle Branch of the Patapsco River. The network of BES long-term monitoring sites in and around the Gwynns Falls ranges from completely forested "reference" sites to sites in suburban and urban subwatersheds in which impervious cover varies from 0-40 percent, based on 30-meter (m) resolution Digital Elevation Models (DEMs) and the 2011 USGS National Land Cover Dataset (updated 2014, https://landcover.usgs.gov/glc/).

The five BES Gwynns Falls monitoring sites included in this study are Glyndon in the suburban headwaters, Gwynnbrook farther downstream in a suburban area, Villa 


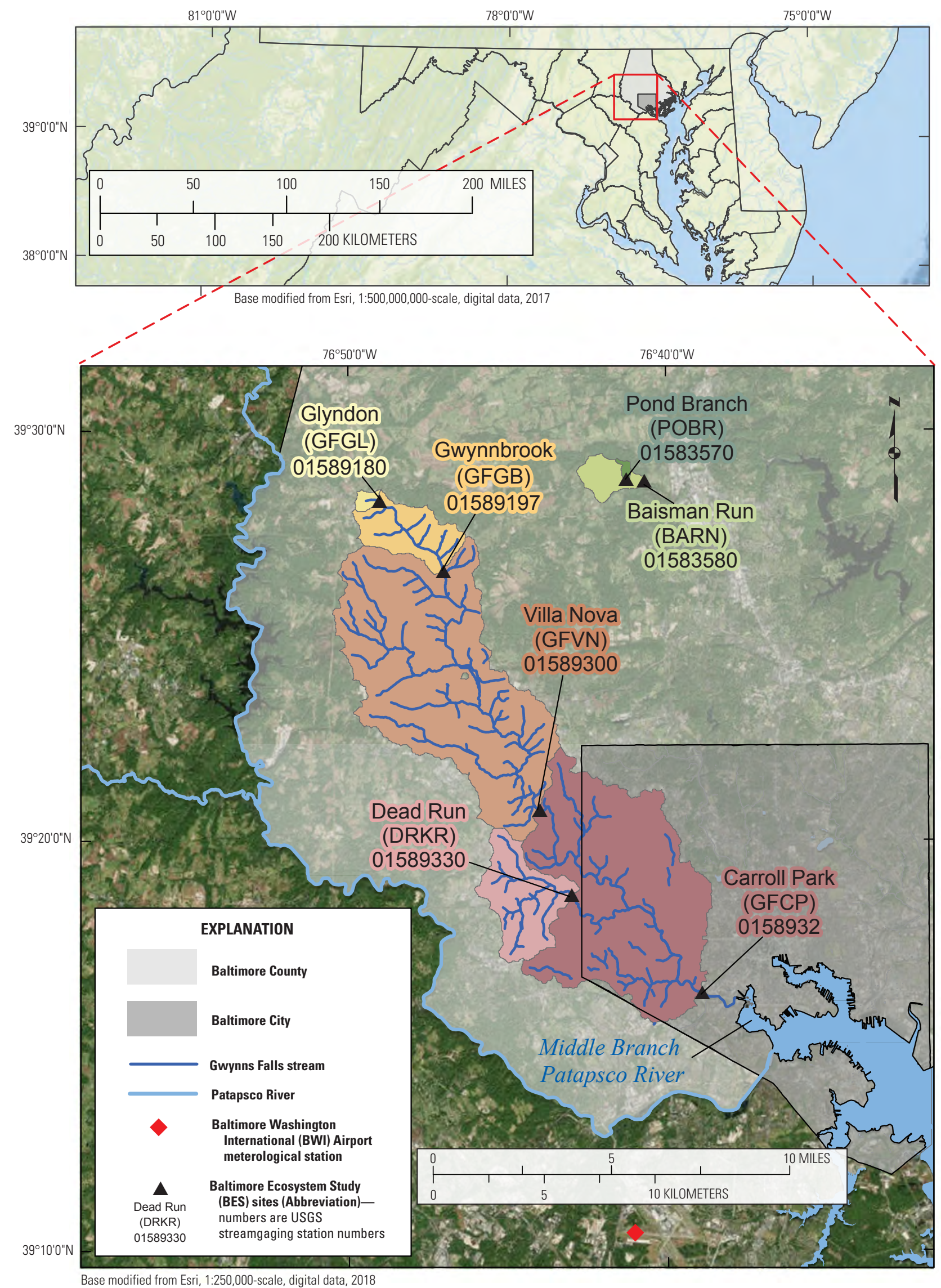

Figure 1. Location of Gwynns Falls watershed and subwatersheds, and Baltimore Ecosystem Study Sites, Baltimore County and Baltimore City, Maryland. (BWI, Baltimore Washington International Airport; USGS, U.S. Geological Survey; BES, Baltimore Ecosystem Study) 
Nova at the suburban/urban boundary, and Dead Run and Carroll Park in urban areas (fig. 1). Glyndon, Gwynbrook, Villa Nova, and Carroll Park sites are on the main stem of the Gwynns Falls, whereas the Dead Run site is on a tributary to Gwynns Falls (fig. 1). Two more sites, Pond Branch in a forested area and Baisman Run in a suburban unsewered area, are used as reference sites and are within the Gunpowder Falls watershed (fig. 1). The watershed and subwatershed boundaries were delineated using a 30-m resolution USGS DEM (2011, updated 2014, https://landcover.usgs.gov/glc/).

Annual assessments conducted by MDE to fulfill requirements of the Clean Water Act (sections 305(b) and 303(d); MDE, 2014) show that the Gwynns Falls stream is impaired to varying degrees by several constituents, including fecal coliform bacteria, total phosphorus, total suspended solids, chloride, and polychlorinated biphenyls. In addition, specific goals for total nitrogen, total phosphorus, and total sediment are mandated by Maryland as a partner in the Chesapeake Bay Restoration Agreement (EPA, 2010). Impaired streams that do not meet the water-quality criteria designated by the State of Maryland are typically required to implement a management strategy and actions to bring streams into compliance.

\section{Land-Cover Change}

The spatial and temporal variation of land cover is an important factor to consider when studying water quality. To assess the amount of land-cover change that occurred within the Gwynns Falls subwatersheds during the study period, percent land-cover change from 2001 to 2011 was calculated for each subwatershed using National Land Cover Database 30-m resolution raster datasets (Homer and others, $2007,2015)$. The change in land cover $(\Delta \mathrm{LC})$ was assessed by reclassifying raster values (RV) from 2001 and 2011 to one of eight general land-cover categories, including water, developed, barren, forest, shrubland, herbaceous, agriculture, and wetlands. The land-cover values were compared using the following equation:

$$
\left(R V_{2001} * 10\right)+R V_{2011}=\Delta L C
$$

Change in land cover was assessed by examining the two digit number generated $(\triangle \mathrm{LC})$ where the first digit represents the 2001 value, and a second digit represents the 2011 value. Land-cover change was identified by differences in the two digits of the land-cover number (for example, $42=$ forest to developed land-cover change). For each category, the number of raster cells was summed to get a $\Delta \mathrm{LC}$ raster count, then the number of cells for each category $(\triangle \mathrm{LC})$ was multiplied by the area of an individual raster cell $\left[900\right.$ square meters $\left.\left(\mathrm{m}^{2}\right)\right]$ to calculate land-cover change area by using
Subsequently, the percent land-cover change for each category was calculated by using

$$
\begin{aligned}
& \text { Percent LC Change }=(\text { Land-Cover Change Areal } \\
& \text { Subwatershed Area }) * 100
\end{aligned}
$$

where the subwatershed area was estimated using the sum of all areas for the eight categories.

Minimal land-cover change occurred in the watersheds of interest over the period analyzed (fig. 2), despite estimates of increasing urbanization across the Chesapeake Bay watershed, likely as a result of the already high percentage of impervious surface of the watershed at the start of the study. This is consistent with previous studies that estimated impervious surface change over roughly the same time frame, which indicated that older, established cities have relatively stable impervious surface over time (Sexton and others, 2013). The greatest percent change in land cover ( 7.65 percent) occurred in the Pond Branch forested reference subwatershed, and all of this change was from forested to herbaceous land cover, likely associated with natural gas line maintenance, which should have minimal effect on the hydrology and water quality of the subwatershed. Change in all other subwatersheds, except Villa Nova, was estimated to be about 2 percent; change was predominantly from forest and agricultural to developed land cover. Land-cover change within the Villa Nova subwatershed was estimated to be about 3.5 percent; change was predominantly from forest and agriculture to developed (fig. 2).

The minimal land-cover change of about 2 percent across the entire watershed (represented by the Carroll Park subwatershed) indicates that land-cover change is unlikely to be a major factor affecting water-quality trends across the watershed during the period of interest. If the subwatersheds were not as urbanized as they are, smaller changes in land cover could be more significant. However, nearly all subwatersheds in Gwynns Falls watershed were already dominated by developed land cover (fig. 2). There is, however, considerable variation in land cover and water quality between subwatersheds.

\section{Change in Precipitation}

Assessing changes in water quality over time in a changing climate can be difficult and can complicate evaluation of the effects of BMPs. Variability in climate and the incidence of climate extremes, such as increased heavy precipitation (greater than 1.9 centimeter $(\mathrm{cm})$ in less than 48 hours), are increasing (Walsh and others, 2014). Increased precipitation has been shown to result in greater delivery of contaminants to receiving waters as a result of declines in residence time and uptake in the watershed (Morse and Wollheim, 2014; Kaushal and others, 2008; Chiwa and others, 2010; Bettez and others, 2015).

Owing to the lack of reliable meteorological stations within the watershed, data from a nearby regional meteorological station at Baltimore-Washington International (BWI) 


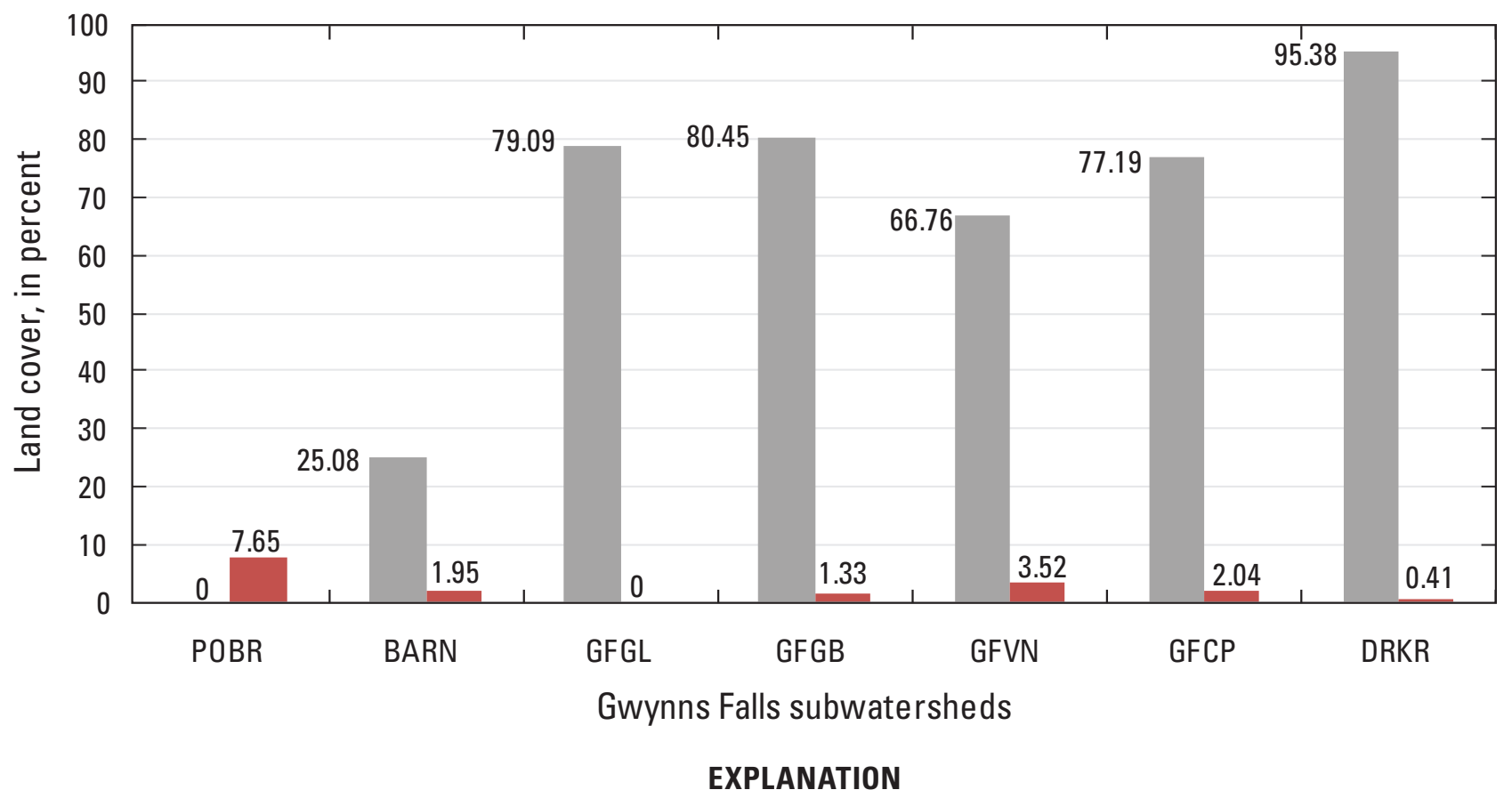

Percent developed land cover

Percent total land cover change

Figure 2. Developed land cover and change in land cover, Gwynns Falls subwatersheds, Baltimore County and Baltimore City, Maryland, 2001-11. (POBR, Pond Branch; BARN, Baisman Run; GFGL, GyIndon; GFGB, Gwynnbrook; GFVN, Villa Nova; GFCP, Carroll Park; DRDK, Dead Run)

Airport (fig. 1) operated by the National Oceanic and Atmospheric Administration (www.ncdc.gov, accessed January 2017) was used to examine annual and seasonal trends in precipitation and runoff producing storms at the regional level. The total number and proportion of 48- and 24-hour runoff producing storms (defined as greater than $1.9 \mathrm{~cm}$ of precipitation over the time period; Lawrence and others, 2012) were calculated annually and seasonally. Annual time frames were based on the October 1-September 30 water year, and the seasons are fall (October-December), winter (January-March), spring (March-June) and summer (July-September). Statistical analysis was performed using R (Version 3.4.0; R Development Core Team, 2016).

Over the study period, the annual precipitation amount showed a moderately significant increase (fig. 3). This increase was driven by a significant increase in winter precipitation (fig. 4); winter is the season with the lowest precipitation. The number and proportion of storms occurring in the winter significantly increased (figs. 5 and 6), and the proportion of storms occurring in the summer significantly decreased during the time frame of the study (fig. 5).

Increased winter precipitation is important for area stakeholders to consider, largely because contaminant loads are dominantly transported in winter as a result of the lack of evapotranspiration during this season. Moreover, BMPs that rely on vegetation and other biological processes are often not as effective in the non-growing season as in the growing season. Increases in runoff producing storms can exacerbate the occurrence of wet weather SSOs.

\section{Is the Water Quality of the Gwynns Falls Watershed Changing?}

Water-quality trends were assessed in the Gwynns Falls subwatersheds and reference watersheds to establish a basis for evaluation of the primary factors affecting these trends. The data compilation effort and methods used are briefly described in the section. A summary of these trends is presented, and the trend results are discussed in relation to other publications that describe the conditions of Baltimore City and Baltimore County waterways.

Loads and flow-weighted concentrations were calculated, and trends are described, for a range of water-quality constituents. For purposes of comparison to regulatory targets such as TMDLs, contaminant loads, or the cumulative mass of a constituent delivered to a location over a period of time (for example, 1,000 kilograms of total phosphorus per year), were calculated. However, loads are highly affected by flow 


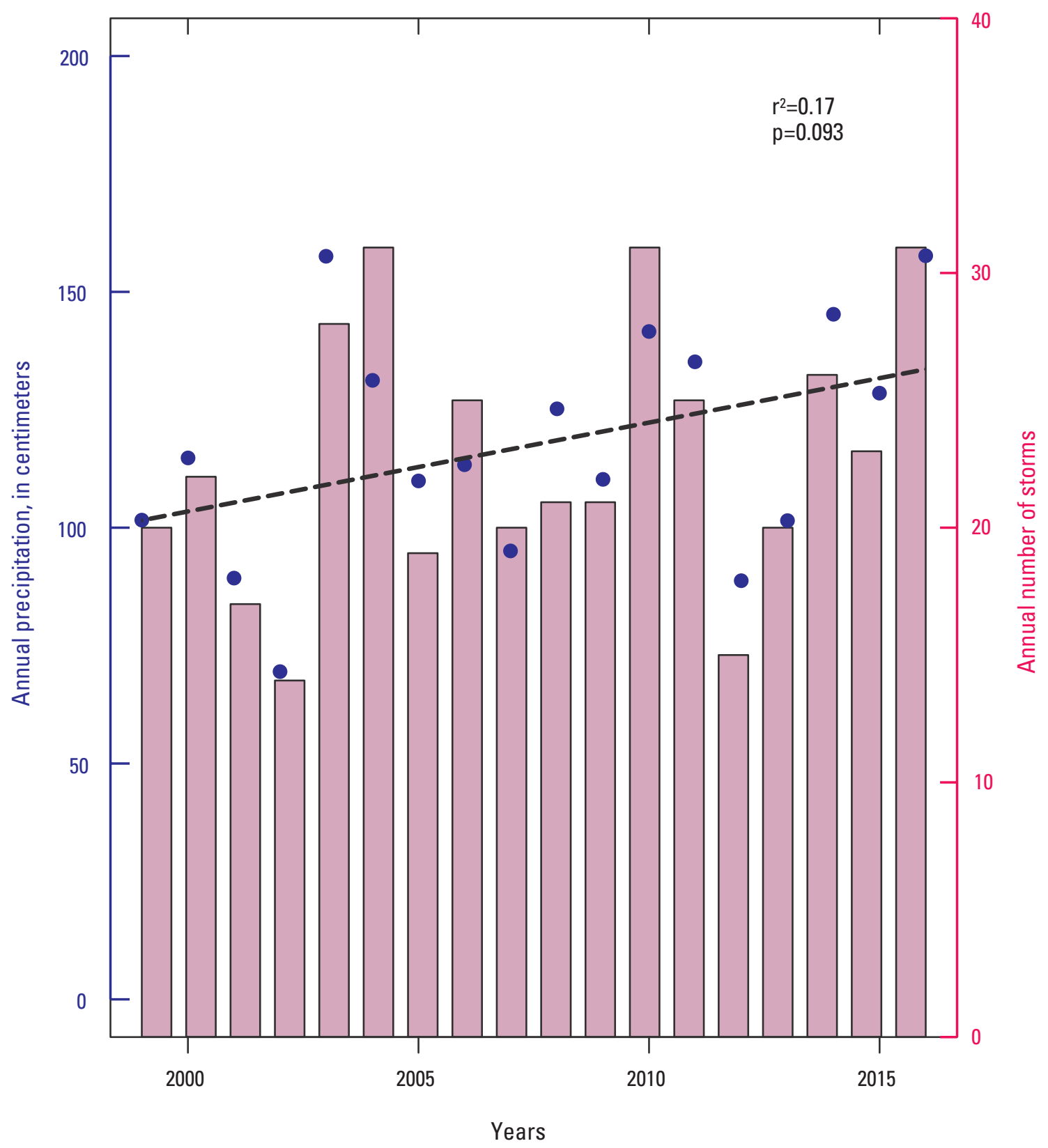

\section{EXPLANATION}

Runoff producing storms

Trend line, annual precipitation

- Annual precipitation

Figure 3. Annual precipitation and annual count of runoff producing storms, Baltimore Washington International Airport meteorological station, Maryland, water years 1999-2016. (Dashed line, $0.05<\mathrm{p}<0.1$ ). 


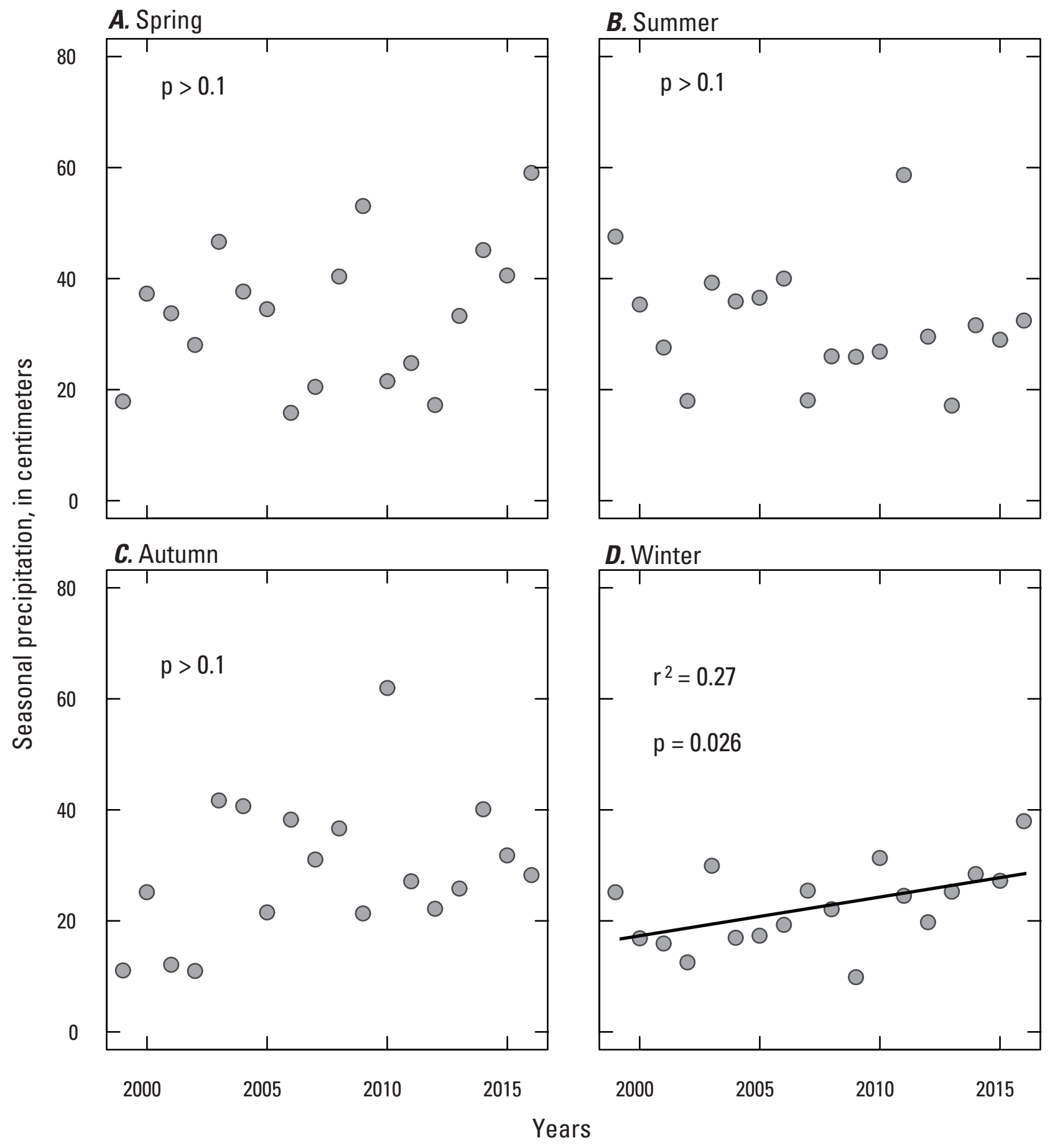

\section{EXPLANATION}

\section{Trend line}

Figure 4. Trends in seasonal precipitation, water years 1999-2016, Baltimore Washington International Airport meteorological station, Maryland: $A$, spring, $B$, summer, $C$, autumn, and $D$, winter. 


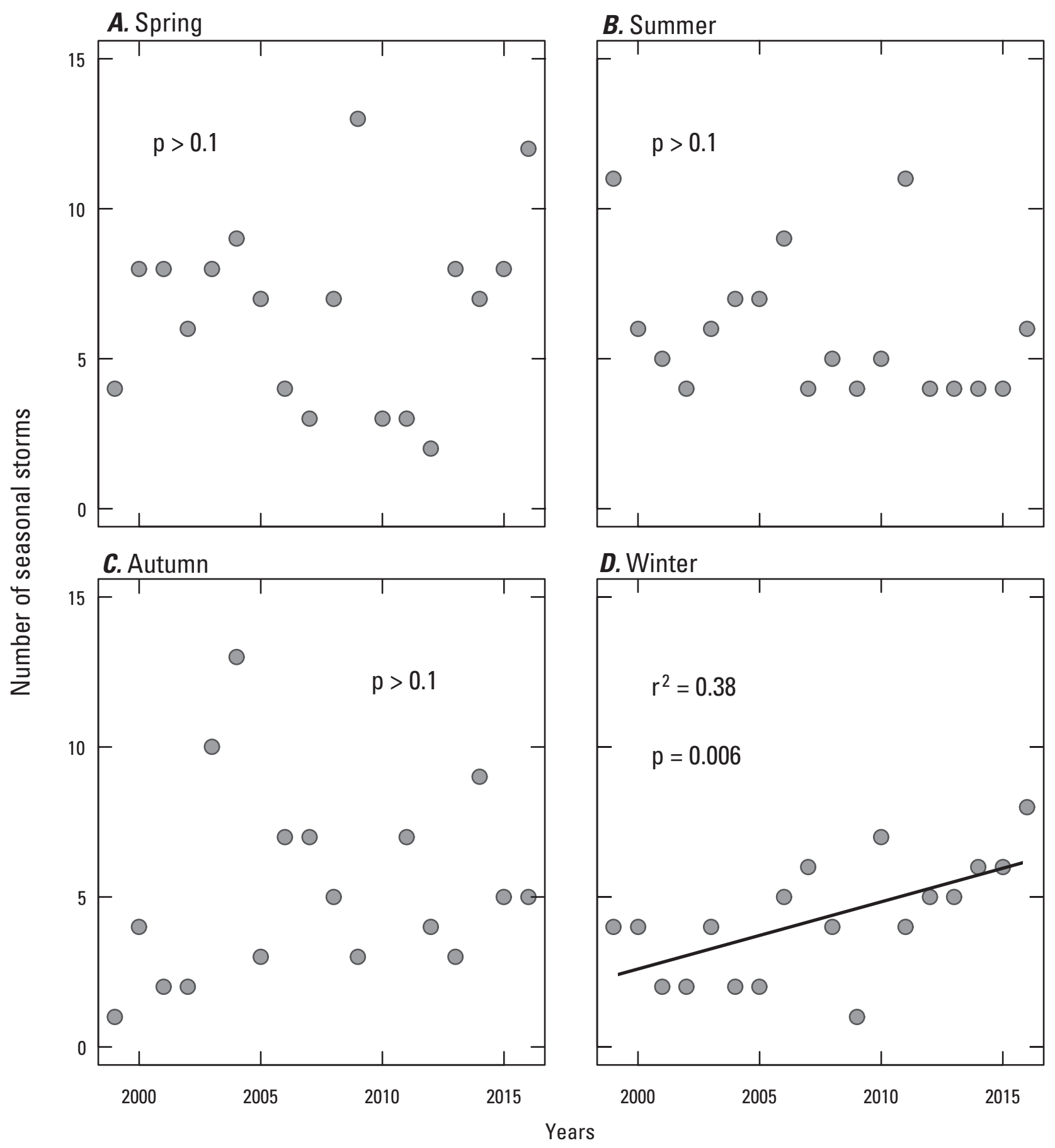

EXPLANATION

\section{Trend line}

Figure 5. Trends in seasonal runoff producing storms, water years 1999-2016, Baltimore Washington International Airport meteorological station, Maryland: $A$, spring, $B$, summer, $C$, autumn, and $D$, winter. 


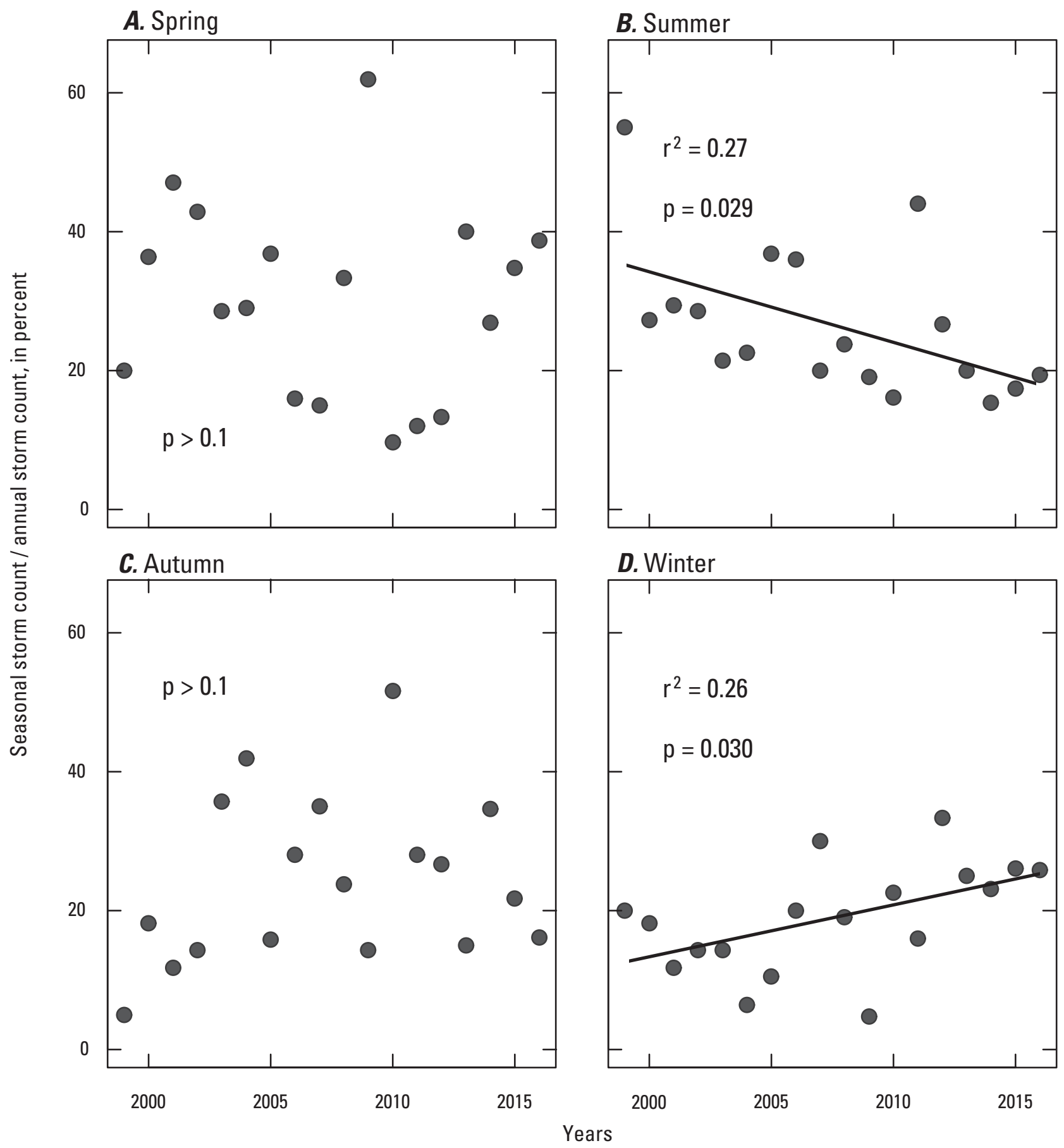

EXPLANATION

Figure 6. Trends in contribution of seasonal runoff producing storms compared to total annual storms, water years 1999-2016, Baltimore Washington International Airport meteorological station, Maryland: $A$, spring, $B$, summer, $C$, autumn, and $D$, winter. 
rate (and therefore climate); therefore, in addition to loads, flow-weighted concentrations (FWCs) were calculated as the total constituent load divided by the total annual flow. Constituent FWCs are important to consider because they normalize for fluctuations in precipitation and streamflow. A FWC is the mass of a constituent relative to the volume of water (for example, 100 milligrams of total phosphorus per liter of water). By normalizing for flow conditions, it is possible to evaluate management changes (for example, implementation of BMPs) over time irrespective of relatively wet or dry years.

\section{Compilation of Data and Estimates of Water- Quality Trends}

Streamflow and water-quality constituent data were compiled from various sources, including USGS (streamflow only), BES LTER, Baltimore City Department of Public Works (DPW), and Baltimore County Department of Environmental Protection and Sustainability (DEPS) (table 1). Sample frequency ranged from instantaneous (streamflow by USGS) to weekly (BES) to monthly (Baltimore City DPW and Baltimore County DEPS). Methods of data collection for the datasets are described elsewhere (Groffman and others, 2004; USGS National Water Information System at https://waterdata.usgs.gov/md/nwis/sw for USGS streamgaging stations shown in fig. 1; Baltimore City DPW and Baltimore County DEPS, Sampling and Analysis Standard Operating Procedures, written commun., 2017). All BES monitoring is performed weekly with the collection of grab samples at USGS streamgaging stations (fig. 1) and has previously been shown to represent water quality over the full range of flow conditions (Groffman and others, 2004), whereas DPW and DEPS monitoring is not always directly associated with a streamgaging stations. From the compiled dataset from DPW and DEPS, monitoring sites at or in close proximity to [approximately within $152.4 \mathrm{~m}$ or 500 feet (ft)] a USGS streamgaging station were selected for load and FWC calculations. Sampling locations that were greater than $152.4 \mathrm{~m}$ from a streamgaging station or had tributaries entering the main stem of Gwynns Falls within $152.4 \mathrm{~m}$ of a streamgaging station were excluded. The results of the data compilation are provided in Woytowitz and others (2018).

Annual constituent loads and annual FWCs were calculated using daily mean discharge measurements from USGS streamgaging stations and corresponding constituent monitoring dates. Subsequently, loads and FWCs were extrapolated as a constant value between sampling events to estimate a daily load or concentration, and daily loads or concentrations were summed to estimate an annual load over the water year for a given constituent.

Table 1. Summary of water-quality constituents, data sources, and dates of data collectiona.

[GFCP, Carroll Park; GFVN, Villa Nova; GFGL, Glyndon; GFGB, Gwynnbrook; DRKR, Dead Run]

\begin{tabular}{|c|c|c|c|}
\hline Water-quality constituent & Subwatersheds & Data source & Dates of data collection ${ }^{\mathrm{a}}$ \\
\hline Streamflow & All & $\begin{array}{l}\text { U.S. Geological Survey, https://waterdata.usgs.gov/md/nwis/ } \\
\text { current/?type=flow\&group_key=basin_cd }\end{array}$ & $\begin{array}{l}\text { 1998-2016, continuous } \\
\text { record }\end{array}$ \\
\hline $\begin{array}{l}\text { Nitrate, phosphate, sulfate, } \\
\text { total nitrogen, total } \\
\text { phosphorus, chloride }\end{array}$ & All & $\begin{array}{l}\text { Baltimore Ecosystem Study Long-Term Ecological Research, } \\
\text { http://beslter.org/data_browser.asp }\end{array}$ & 1998-2013, weekly \\
\hline Escherichia coli & GFCP & $\begin{array}{l}\text { Baltimore City Department of Public Works, http://dpwapps.balti- } \\
\text { morecity.gov/cleanwaterbaltimore/surface-water-quality-data/ }\end{array}$ & 2009-2012b , monthly \\
\hline Fecal and total coliform & GFCP & $\begin{array}{l}\text { Baltimore City Department of Public Works, http://dpwapps.balti- } \\
\text { morecity.gov/cleanwaterbaltimore/surface-water-quality-data/ }\end{array}$ & 1999-2008, monthly \\
\hline $\begin{array}{l}\text { Total keldahl nitrogen and } \\
\text { total suspended solids }\end{array}$ & $\begin{array}{l}\text { GFVN, GFGL, } \\
\text { GFGB, DRKR }\end{array}$ & $\begin{array}{l}\text { Baltimore Department of Environmental Protection and Sustain- } \\
\text { ability, https://www.baltimorecountymd.gov/Agencies/environ- } \\
\text { ment/watershedsandmonitoring.html }\end{array}$ & 2011-2016, monthly \\
\hline
\end{tabular}

${ }^{a}$ Relevant water-quality monitoring stations and associated constituent data and sampling date summarized in Woytowitz and others (2018).

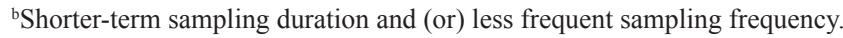


Instantaneous load was calculated by using

$$
\begin{aligned}
& \text { Instantaneous Load } \text { Lilogram } / \text { second })(\text { kilo } \\
& C_{i}(\text { kilogram } / \text { liter }) \times Q_{i}(\text { liter } / \text { second })
\end{aligned}
$$

where

$$
\begin{array}{ll}
\mathrm{C}_{i} & =\text { Constituent concentration at time step } i, \text { and } \\
\mathrm{Q}_{i} & =\text { mean daily discharge, time step } i .
\end{array}
$$

We assumed a constant instantaneous load between monitoring events, which allowed us to calculate a between-event load estimate by using

$$
\begin{aligned}
& \text { Between-event load (kilogram) = Instantaneous Load } \\
& \text { (kilogram/second) } x\left[T_{i+1}-T_{i}\right] \text { (second) }
\end{aligned}
$$

where $\left[\mathrm{T}_{i+1}-\mathrm{T}_{i}\right]=$ Time between sampling dates.

After calculating loads between each sampling event, annual loads were calculated by using

$$
\operatorname{Load}_{A}(\text { kilogram })=\Sigma\left[C i x Q_{i} \times\left[T_{i+1}-T_{i}\right]\right]
$$

Annual FWCs were calculated by using

$$
\begin{aligned}
& \text { FWC }(\text { milligram/liter })=[\text { Annual load }(\text { milligram/year })] / \\
& [\text { Annual Q (liter/year })] .
\end{aligned}
$$

Trends were quantified using a linear regression model with the different constituents of interest as dependent variables and water year as the independent variable. Statistical analysis was performed in R (version 3.4.0; R Development Core Team, 2016). Regressions were assessed visually and using Q-Q plots to establish any issues with non-normality of residuals. No major issues with non-normality were found. It was expected that the simplicity of interpretation using nontransformed values outweighed any potential minor deviations from normality.

Although monthly data for Escherichia coli (E. coli), total suspended solids (TSS), ammonia, and fecal and total coliform were compiled (table 1, Woytowitz and others, 2018), these data collection time frames ranged from 3 to 9 years, whereas weekly data for the other constituents were compiled for 15 years. Owing to the shortened timeframe and frequency of sampling, empirical trends for the five constituents are not reported, but fecal and total coliform datasets were retained for consideration in the factors analysis.

\section{Summary of Streamflow and Water-Quality Trends}

Despite the increases in precipitation described above, no trends were observed for annual or seasonal discharge at the seven sites within the study area (fig. 7). However, variability across sites was observed, with the discharge reflecting subwatershed size and high precipitation years. The greatest magnitude of discharge was measured at the Carroll Park streamgaging station, at the outlet of the watershed to the Middle Branch of the Patapsco River (fig. 7). The lack of any significant change in discharge is surprising, based on the observed increases in precipitation and storm events in this study period. It is uncertain what is causing this lack of response. It may be due to the installation of green infrastructure, which may alter precipitation-discharge relations, buffering these urban and suburban watersheds against increases in precipitation (Burgess, 2017). Although winter storms tend to be regional in nature, spring and summer storms can be spotty and vary widely with respect to duration, intensity, and amount of rainfall. Analysis of the data from meteorological station at BWI may affect consideration of this variability.

A summary of all water-quality trends in the seven subwatersheds in the study is provided in table 2. Most of the constituents and subwatersheds show no significant trends over time (greater than $90 \%$ of those considered). In some locations, nitrate, phosphate, and total nitrogen show downward trends and total phosphorus and chloride show upward trends (table 2, figs. 8 and 9). Results are consistent with previously published results examining nitrogen species (Kaushal and others, 2008, 2014; Bettez and others, 2015), and phosphate and total phosphorus (https://cbrim.er.usgs.gov/ trends_query.html? at USGS station Gwynns Falls at Villa Nova) for the same years.

Nitrate and total nitrogen loads follow patterns reflective of watershed size and appear to be largely affected by high precipitation and storm event years, including 2003 (Hurricane Isabel) and 2010 (multiple snow events and Tropical Storm Nicole) (fig. 3, figs. 8A, C). This is consistent with observations by Bettez and others (2015) and Kaushal and others $(2008,2014)$, where increased precipitation and storms were associated with increased export of constituents. Perhaps because of this strong correlation to precipitation variability, there were no significant trends in nitrate or total nitrogen loads in any subwatershed. When normalizing for the variability in streamflow using FWCs (figs. $8 B, D$ ), different patterns emerge, and the variability between years is dampened. A significant increase in nitrate FWC was observed for Dead Run (the most urban subwatershed) but not for the other subwatersheds. Total nitrogen showed a significant decline at the Glyndon headwaters site only (fig. $8 D$ ). The variability and magnitude of nitrate and total nitrogen FWCs do not follow the same patterns with urbanization and watershed size observed for loads (figs. $8 \mathrm{~A}, \mathrm{C}$ ), likely owing to the effect of streamflow on loads. Variability in FWCs is likely driven by variation in nitrogen and nitrate sources (sanitary sewer overflows, septic systems, pet waste, fertilizers) in the seven watersheds.

Phosphate loads remained unchanged or declined at all sites (fig. 9A) with significant declines noted in the headwaters of Gwynns Falls stream at Glyndon, as well as at the urban Dead Run and Carroll Park sites. Total phosphorus significantly increased in the suburban Gwynn Brook site and significantly decreased at Carroll Park, with no significant 


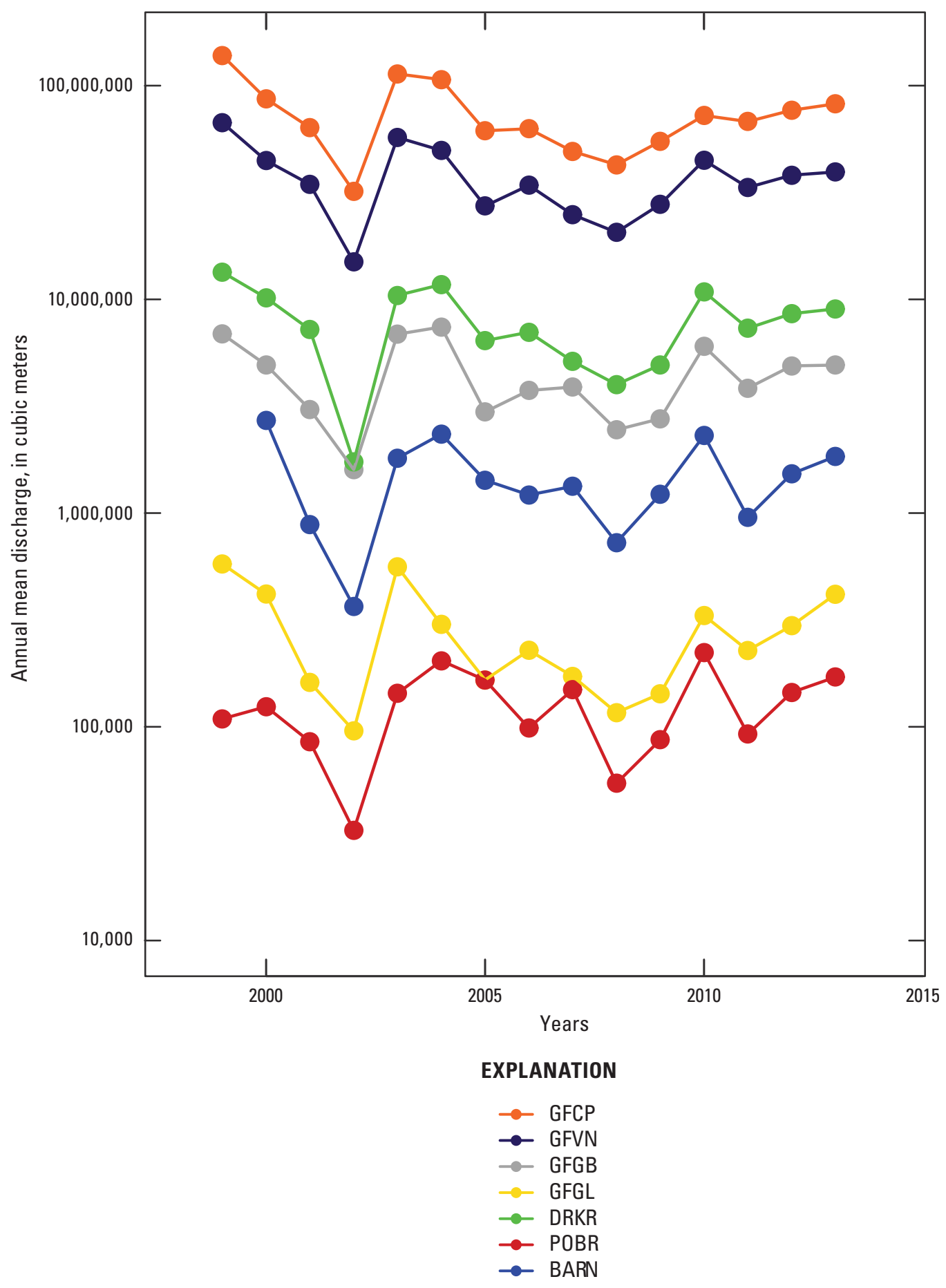

Figure 7. Annual mean surface-water discharge, Baltimore Ecosystem Study sites, Baltimore County and Baltimore City, Maryland, water years 1999-2013. (Site abbreviations are defined in figures 1 and 2) 


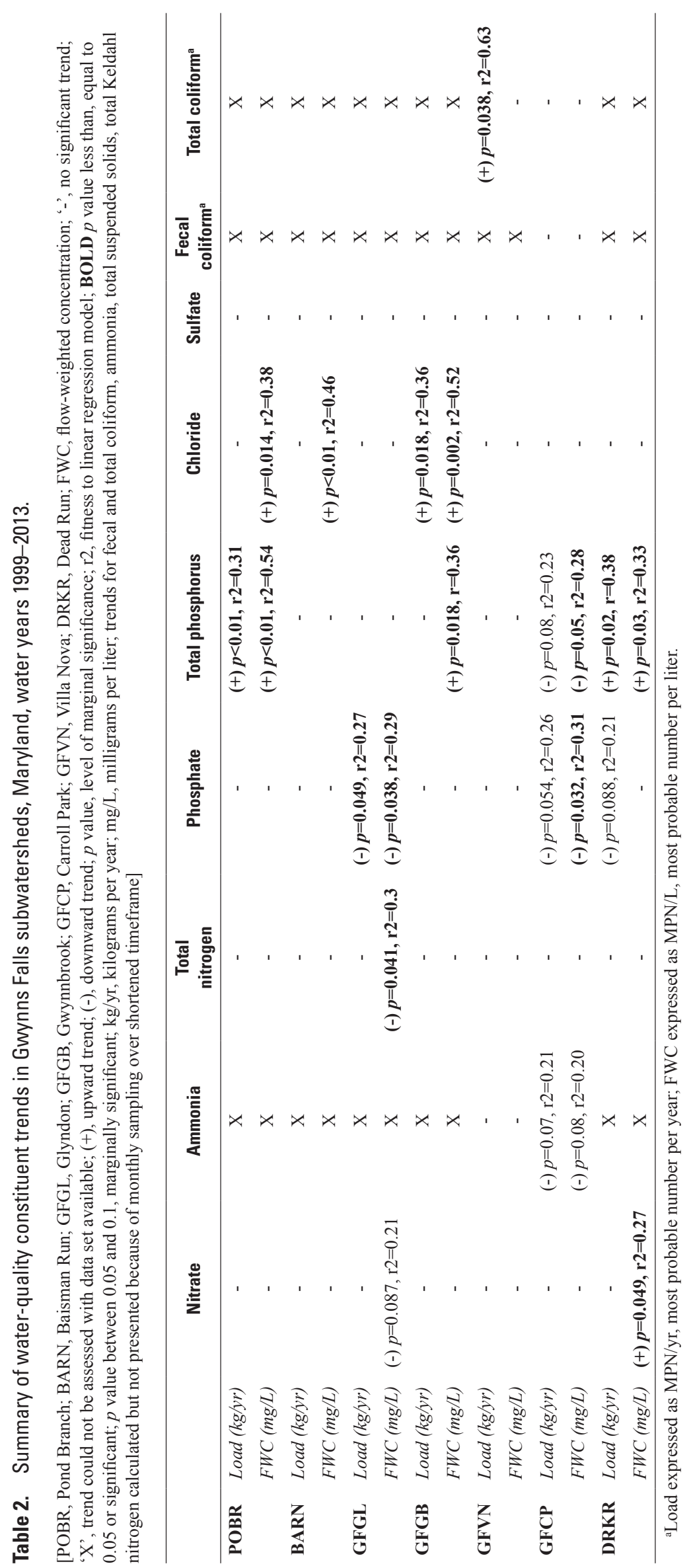



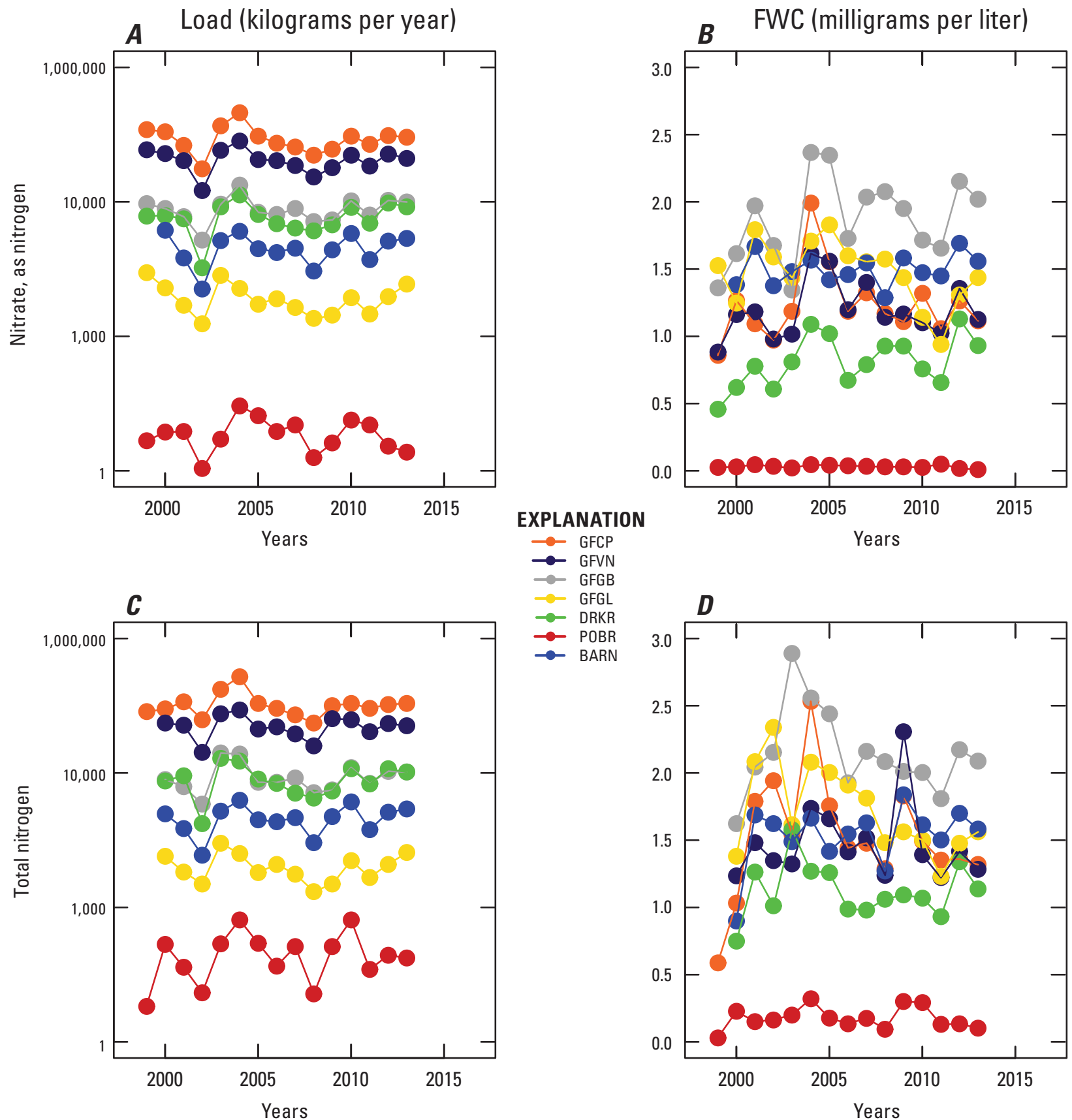

Figure 8. Trends in $A$ and $C$, loads and $B$ and $D$, flow-weighted concentrations of nitrate (as nitrogen) and total nitrogen, Gwynns Falls Carroll Park subwatershed, Maryland, water years 1999-2013. (FWC, flow-weighted concentration. Site abbreviations are defined in figures 1 and 2). 

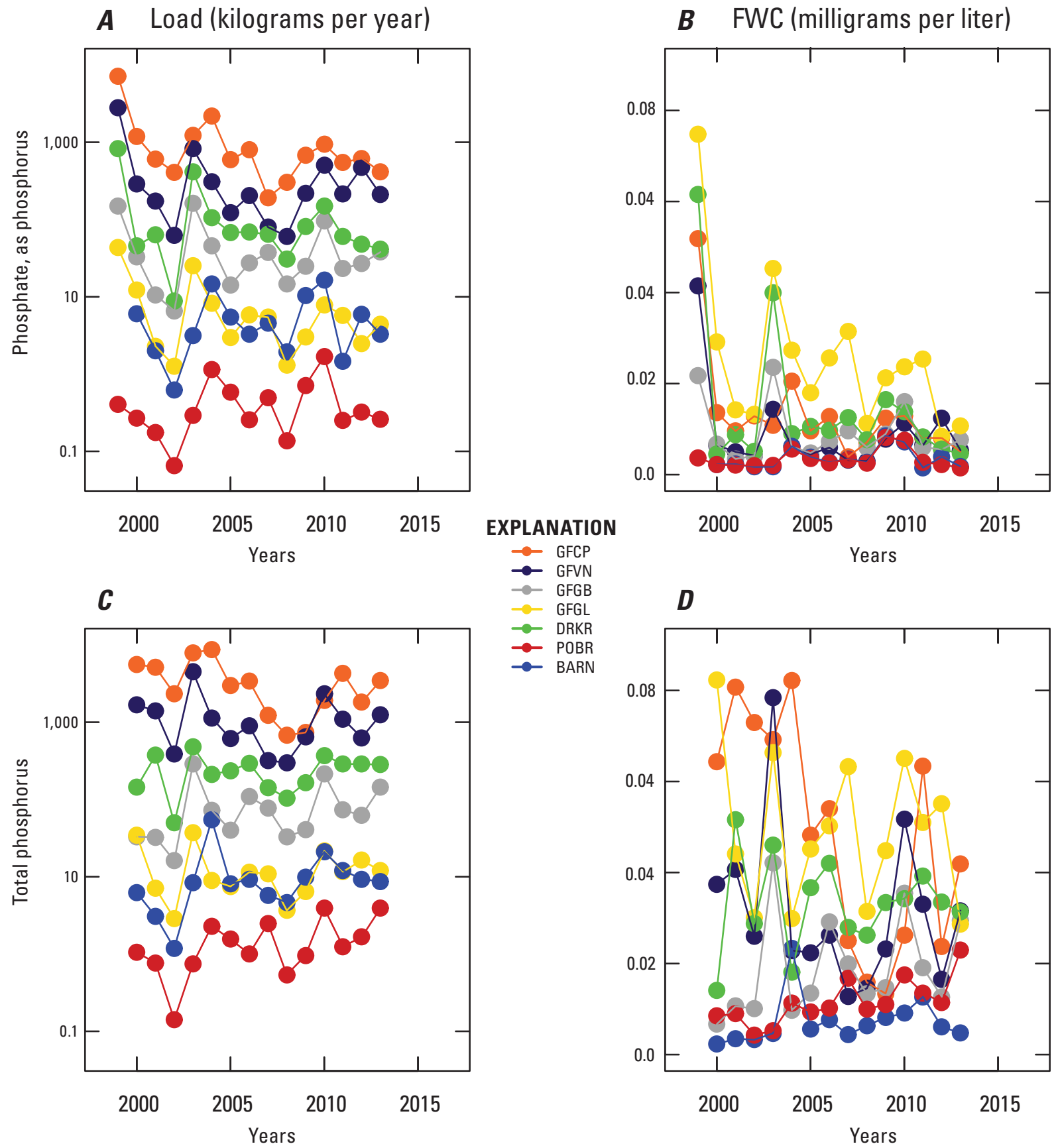

Figure 9. Trends in $A$ and $C$, loads and $B$ and $D$, flow-weighted concentrations of phosphate (as phosphorus) and total phosphorus, Gwynns Falls Carroll Park subwatershed, Maryland, water years 1999-2013. (FWC, flow-weighted concentration. Site abbreviations are defined in figures 1 and 2) 
trends at other sites (figs. $9 C, D$ ). This may indicate that while variable inputs occur across the watershed, export from the overall watershed to receiving waters is declining for total phosphorus (table 2). Unlike nitrogen, these trends were consistent between loads and FWCs, indicating that phosphate and total phosphorus are not as dependent on the streamflow and climate variability as nitrogen.

The variability and maximum load and FWCs of chloride differ from patterns observed for nitrogen and phosphorus (figs. 8, 9), indicating differing sources. There were no significant trends for sulfate at any location (table 2).

In 2011, non-governmental and governmental organizations in Baltimore City worked together to develop the Healthy Harbor Plan with the goal of working toward making the Inner Harbor fishable and swimmable by 2020. One outcome of this effort is the Healthy Harbor Report Card, which was first released in 2012. Although the basis for the report card is rooted in ecological and human health indicator thresholds, based on water-quality constituent concentrations (EcoCheck, 2011), rather than individual constituent loads, it is worthwhile to consider the results of the long-term trends at Carroll Park, the most downstream site in relation to these goals. From 2012 to 2014, the report cards indicated slightly improved annual scores for the Gwynns Falls watershed, with improvements mainly noted for total phosphorus (Waterfront Partnership, 2012, 2013, 2014), which are similar to the trends observed in this study. Despite investments in both gray (piped stormwater and sanitary sewer systems) and green (structural best management practices) infrastructure to improve water quality, total phosphorus is the only constituent identified as an impairment to the Gwynns Falls watershed. Chesapeake Bay showed improving water quality over the study time frame at Carroll Park. Other constituents of concern for impairment of the watershed either increased or decreased at Glyndon at the headwaters of the watershed but showed no change at the urban watershed outlet at Carroll Park. Given the limited datasets for TSS, ammonia, E. coli, and fecal coliform, no apparent trends could be determined for these constituents. Although the lack of improvement at Carroll Park may appear discouraging, there are no constituent values that indicate a degradation of water quality at Carroll Park (table 2), which is encouraging given the increases in precipitation that have occurred. Note that while the original gray infrastructure repairs were initiated during 2002-05, there are considerable improvements planned for the next 10 years (U.S. Department of Justice, 2017). Similarly, while jurisdictions have been monitoring and working under MS4 permits throughout the entire study time frame, the bulk of the watershed restoration (for example, reduction of impervious surface) occurred or is planned for post-2013 (Baltimore City Department of Public Works, 2015). This underscores the need for continued assessment during these ongoing efforts.

\section{What Factors are Affecting Water- Quality Trends in the Gwynns Falls?}

Following the empirical estimation of constituent loads and FWCs, statistical assessment was conducted to further explore the factors affecting water-quality trends in Gwynns Falls watershed. The data compilation effort, references to methods, and a summary of the primary factors determined to affect water quality are summarized in relation to regulatory requirements and economic investments. Of the various factors examined, aging gray infrastructure and the resulting SSO occurrences, as well as the implementation of green infrastructure BMPs, appeared to have the greatest effect on water quality at the watershed scale and are the focus of the sections that follow.

\section{Evaluating Relations between Water Quality and Potential Factors of Influence}

A summary of the compiled factors of influence along with the data sources and date ranges is provided in table 3 and was published in Woytowitz and others (2018). Most factors can be categorized as either gray infrastructure (related to the piped stormwater and sanitary sewer systems) or green infrastructure (related to BMPs). There were several factors that were unavailable and were not included in the analyses. These include fertilizer use, sewer repairs corresponding to the Baltimore City Consent Decree prior to 2013, and BMPs in Baltimore City; these factors were few in number during the time frame of interest.

Most information compiled from the city and county governments was georeferenced, and therefore Baltimore County BMPs, Baltimore City and County SSOs, water main breaks and leaks, and repairs were extracted to each subwatershed by using ArcMap (Version 10.5.0; ESRI, 2016) and then exported to Excel to assign data points to particular subwatersheds. Because of the minimal data density in many of the smaller subwatersheds and a desire to understand the possible influence of these factors on the entire watershed, analysis was focused on the largest, and farthest downstream subwatershed, Carroll Park. The data from Carroll Park encompass all upstream subwatershed actions and may be a good representation of the export of constituents in surface water from the watershed as a whole to the receiving waters of the Middle Branch Patapsco River.

Relations between water-quality trends in Carroll Park subwatershed and SSOs or BMPs as factors were examined through multiple data fields, including count, mean, median, and total duration of SSO, and SSO volume, as well as count, mean, median, and total cumulative storage volume and drainage area for BMPs. It was assumed that once BMPs were implemented they would function as intended over time and therefore were considered cumulative over the period of interest. 
Table 3. Summary of compiled factors of influence, data sources, and date ranges for factors.

\begin{tabular}{|c|c|c|}
\hline Factor & Data source & Date range \\
\hline Sewer repairs (count, length) & Baltimore City Department of Public Works & $2013-2015$ \\
\hline $\begin{array}{l}\text { Sanitary sewer overflows } \\
\text { (count, duration, volume) }\end{array}$ & Baltimore City Department of Public Works & 2003-2016 \\
\hline Water main breaks and leaks (count) & Baltimore City Department of Public Works & $2002-2016$ \\
\hline Road salt (mass applied city wide) & Baltimore City Department of Public Works & 1999-2015 \\
\hline $\begin{array}{l}\text { Sanitary sewer overflows } \\
\text { (count, duration, volume) }\end{array}$ & Baltimore County Department of Environmental Protection and Sustainability & $2001-2016$ \\
\hline Water main breaks and leaks (count) & Baltimore County Department of Environmental Protection and Sustainability & $2001-2016$ \\
\hline Road salt (mass applied) & Baltimore County Department of Environmental Protection and Sustainability & 2000-2015 \\
\hline
\end{tabular}

Road salt application was estimated on the basis of the total number of road lane miles (linear road miles multiplied by 2.5) within each individual subwatershed multiplied by an annual road salt application rate (metric tons per lane mile). The number of lane miles was quantified in each watershed as the sum of the Maryland State Highway Administration and National Highway System lane miles (Maryland State Highway Administration, 2015, https://data-maryland.opendata.arcgis.com/datasets/0db7280f6a024e498f9b706cd656 8cc6_3). These lane miles were divided into those managed by Baltimore County and those managed by Baltimore City. A per-lane-mile road salt application rate was calculated by dividing the total road salt applied (in metric tons, published in MS4 annual reports for each year in the study period) in a given year by the total lane miles within Baltimore County or Baltimore City. Finally, the watershed-specific county or city lane miles were multiplied by the county or city annual road salt application rate to estimate the watershed-specific annual mass of road salt applied by the county and city. Ultimately, the county and city road salt totals were added to get a watershed-specific estimate of total mass of road salt (metric tons) applied in a given watershed.

Univariate relations between explanatory factors and constituent loads and FWCs were explored with linear regression models in R (version 3.4.0; R Development Core Team, 2016). Relations with $p$ values of less than or equal to 0.05 were considered to be significant. Marginally significant relations, those correlations falling between 0.05 and 0.1 were retained. Although it is recognized that univariate analysis with linear regression is a simplified approach to this complex problem, it was the goal of this initial study to examine as many factors as possible throughout the watershed and initiate the analysis of the data. Follow-up studies would benefit from non-linear and multivariate analyses using the database that has been compiled, as well as expanding upon the time scale of the study and the factors analyzed.

Results of the analysis of factors influencing the waterquality trends are summarized in table 4 . These relations, specifically those between gray infrastructure factors and nutrient (mainly nitrogen) and bacteria export, and green infrastructure and phosphorus export are described in more detail in the following sections.

\section{Aging Gray Infrastructure and the Influence of Sanitary Sewer Overflows}

Aging gray infrastructure and the resulting SSOs appear to be a major influence on the water quality of Gwynns Falls, particularly in relation to nitrogen export (nitrate and total $\mathrm{N}$ ) and phosphate export, and to a lesser extent chloride export (table 4). Median SSO volume was significantly positively correlated with annual nitrate and total coliform loads (fig. 10). Similarly, longer duration SSOs were positively correlated with annual total nitrogen and nitrate loads, and annual total nitrogen FWCs (fig. 11). Phosphate load was also positively correlated with SSO duration (table 4, fig. 11B). The lack of correlation between SSOs and fecal bacteria, except for total coliform load (fig. 10B), was likely due to the use of different methods of fecal bacteria monitoring and the short data record (table 1). Therefore, it would be informative to evaluate the relation as the time frame of monitoring is extended. Interestingly, SSO volume was strongly positively correlated with sulfate concentrations, consistent with studies that showed increased export of sulfate was linked to drainage through storm drains in Baltimore City (Kaushal and Belt, 2012).

An additional indication of aging infrastructure is the occurrence of water main breaks and leaks. Unlike SSOs, 


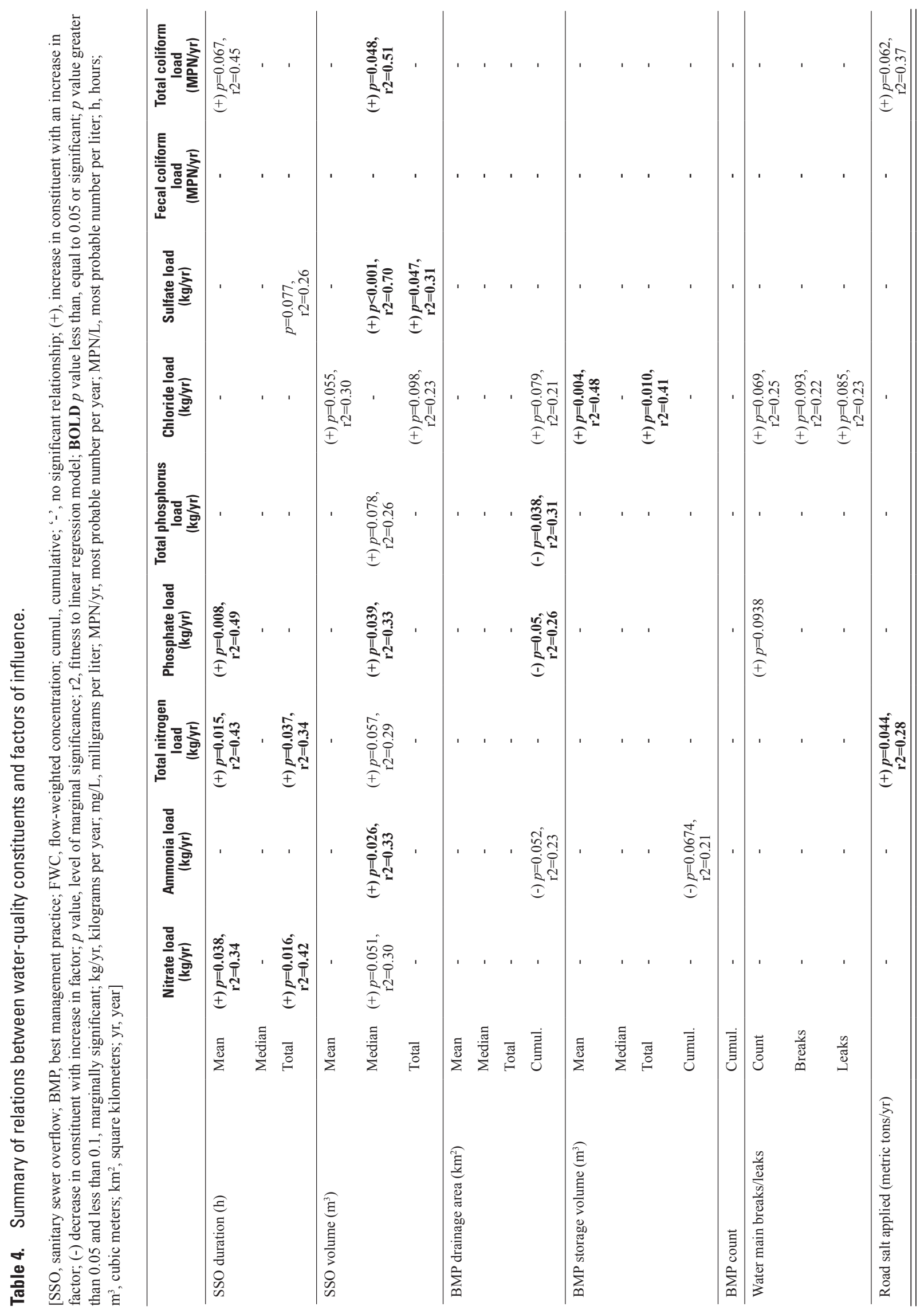




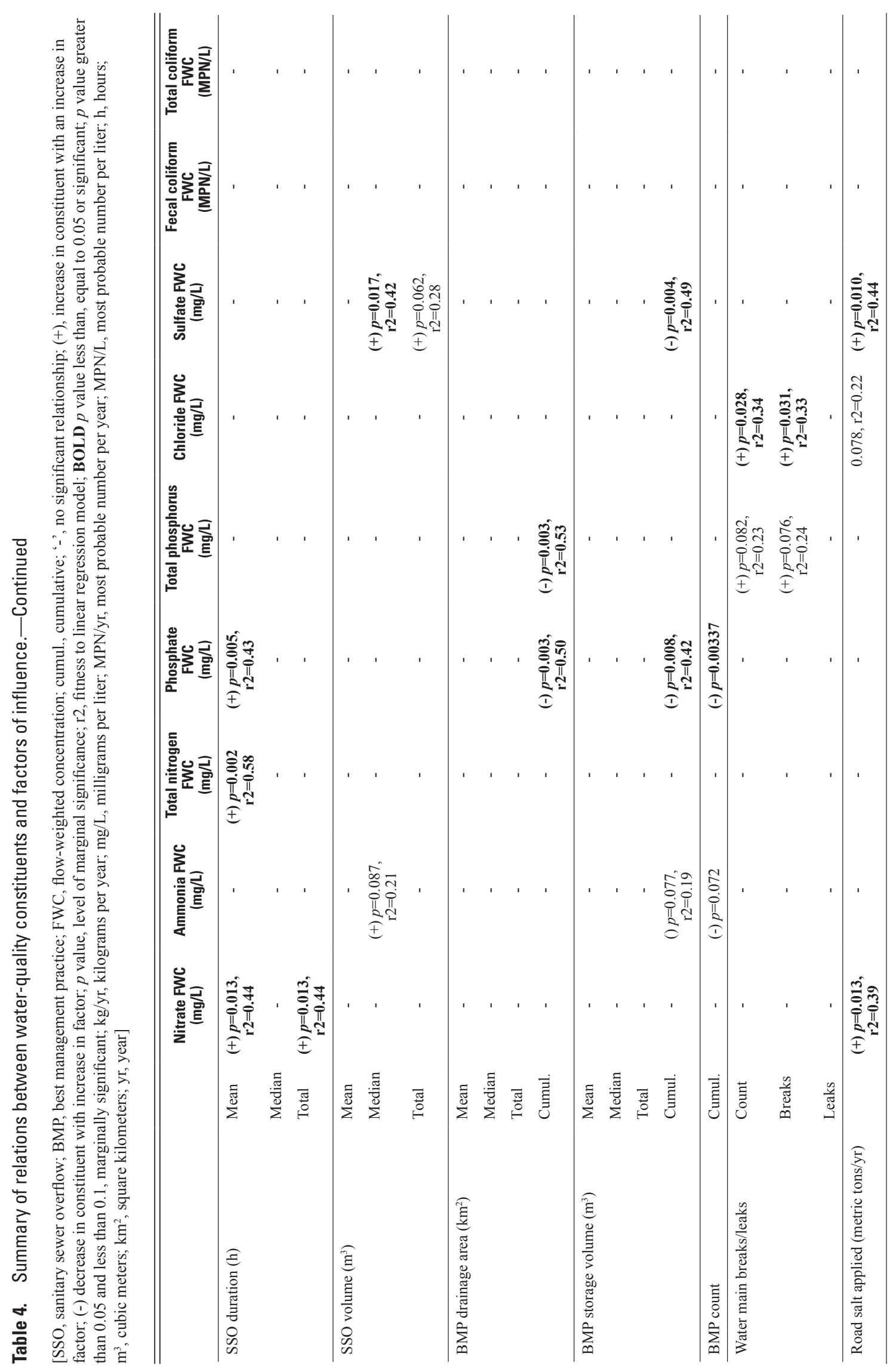



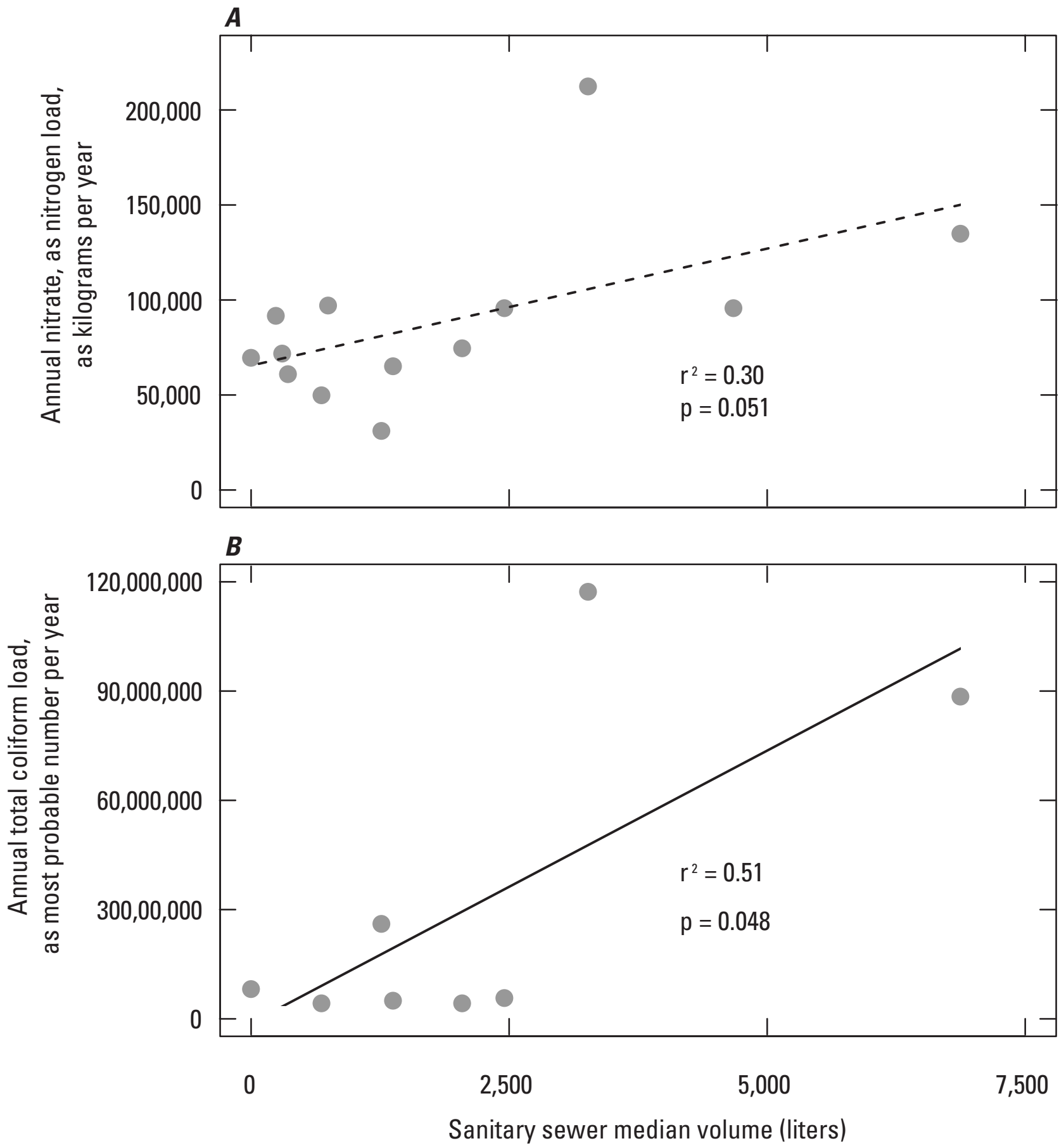

Figure 10. Significant relation of median sanitary sewer overflow volume to $A$, annual nitrate (as nitrogen) load, and $B$, annual total coliform bacteria load, Gwynns Falls Carroll Park subwatershed, Maryland, water years 1999-2013. (Dashed line, 0.05<p<0.1) 


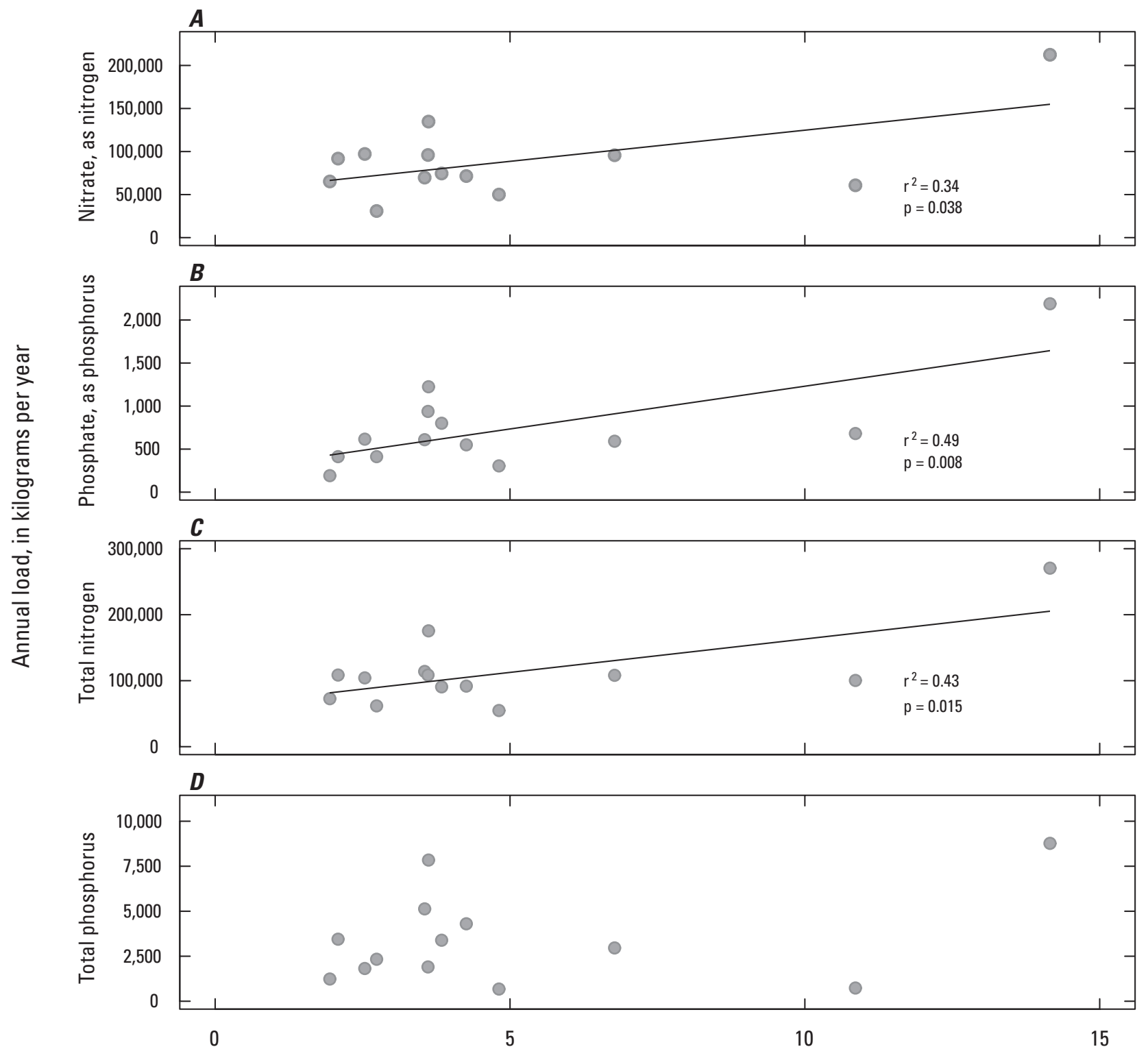

Mean sanitary sewer overflow duration, in hours

Figure 11. Relations of mean total sanitary sewer overflow duration (mean) to $A$, annual nitrate (as nitrogen) load, $B$, annual phosphate (as phosphorus) load, $C$, total nitrogen load, and $D$, total phosphorus load, Gwynns Falls Carroll Park subwatershed, water years 1999-2013. 
volume is not estimated for these events, rather the number of breaks and leaks are tracked by count. FWCs of chloride are positively related to the total count of water main breaks and leaks, and breaks alone, but not leaks alone (table 4).

SSO reduction and elimination is a primary goal of the Consent Decree recently (2017) refiled for Baltimore City (U.S. Department of Justice and others, 2017; Pelton and others, 2015) and ongoing with Baltimore County (U.S. Department of Justice and others, 2005). Specifically, the city plans to reduce more than 99 percent of SSOs in a phased approach, to be completed by 2030, with 83 -percent reduction by 2021 (Baltimore City DPW, presentation from public meeting to discuss sewer Consent Decree, written commun., June 2016). Additional work will assess remaining inflow and infiltration in the sanitary sewer system and address sanitary discharges of unknown origin (Baltimore City DPW, presentation from public meeting to discuss sewer Consent Decree, written commun., June 2016) by the end of 2030. The gray infrastructure investment in Baltimore City through 2019 was estimated to be approximately $\$ 2$ billion.

The correlation of SSOs with nutrient export from the Gwynns Falls presents a challenge for city and county managers tasked with various regulatory requirements related to water quality under different programs with differing compliance time lines. The regulatory targets for nutrient loads are related to the TMDLs for total nitrogen and phosphorus, as specified in the city and county MS4 permits (Baltimore City Department of Public Works, 2015) and the Maryland Watershed Improvement Plan for compliance with the Chesapeake Bay TMDL, which are targeted for 2025. Specific reductions in these nutrient loads are expected to be addressed by reducing the impervious surface by 20 percent, as specified in the MS4 permits. These TMDLs are not explicitly tied to gray infrastructure repairs. Although Illicit Discharge Detection and Elimination is included as a major component of the MS4 permit program, the repairs to gray infrastructure and elimination of SSOs fall predominantly under the regulatory requirements of the Consent Decrees (U.S. Department of Justice and others, 2002, 2005, 2017), which are not expected to be completed until 2030. Many stakeholders, as part of the Healthy Harbor initiative, also have the goal of a fishable and swimmable harbor by 2020. The link between SSOs and nutrients indicates that improvement and repair of the gray infrastructure systems is critical for improvement of urban water quality. Continuing trends analysis could be a valuable tool for evaluating the effectiveness of the ongoing sewer repairs and SSO reductions.

\section{Implementation of Green Infrastructure and Effects of Best Management Practices}

In recent years, there has been an increased focus on rerouting stormwater from the piped, built environment using practices that focus on infiltration to enhance the natural filtering of stormwater, or green infrastructure (EPA, 2017). Baltimore City and County, as well as numerous non-governmental organizations in the region, have implemented green infrastructure to encourage infiltration and reduce stormwater runoff. Various green infrastructure practices are considered to be structural BMPs for water quality (for example, wetlands, bioretention, stream restoration) and can provide impervious surface "credits" for compliance with MS4 permit goals, which are based on assumed pollutant removal efficiencies (MDE, 2014). The presence of these structural BMPs within the county portion of the watershed appears to be a major factor affecting water quality in the Gwynns Falls watershed, particularly phosphorus export (table 4). BMP drainage area is significantly negatively correlated with phosphate and total phosphorus loads and FWC (fig. 12). The same relations were not observed for nitrogen however (table 4). These relations indicate that the county structural BMPs have had a positive downstream effect on phosphorus export from the watershed as a whole (as examined at Carroll Park). Mechanistically, this effect would be driven by the ability of green infrastructure features to retain sediment-bound phosphate. However, analysis does not rule out the possibility that another factor may be driving the relation between BMPs and phosphorus.

Although investments in the MS4 program have been relatively steady (estimated from MS4 annual fiscal reports to be approximately $\$ 10$ million to $\$ 15$ million since 2005), investment has increased to more than $\$ 20$ million in the current permit cycle in Baltimore City, possibly owing to the passage of the stormwater remediation fee in 2013. The annual investment since 2005 in Baltimore County is slightly greater, averaging about \$20 million per year (based on MS4 annual fiscal reports). This investment is expected to increase in the next several years as part of watershed restoration efforts outlined in the Watershed Implementation Plans for Baltimore City and County (for example, Baltimore City Department of Public Works, 2015). Nonetheless, approximately \$100 million was estimated for MS4 investment, which is considerably less than the investment required for the gray infrastructure capital repairs. 

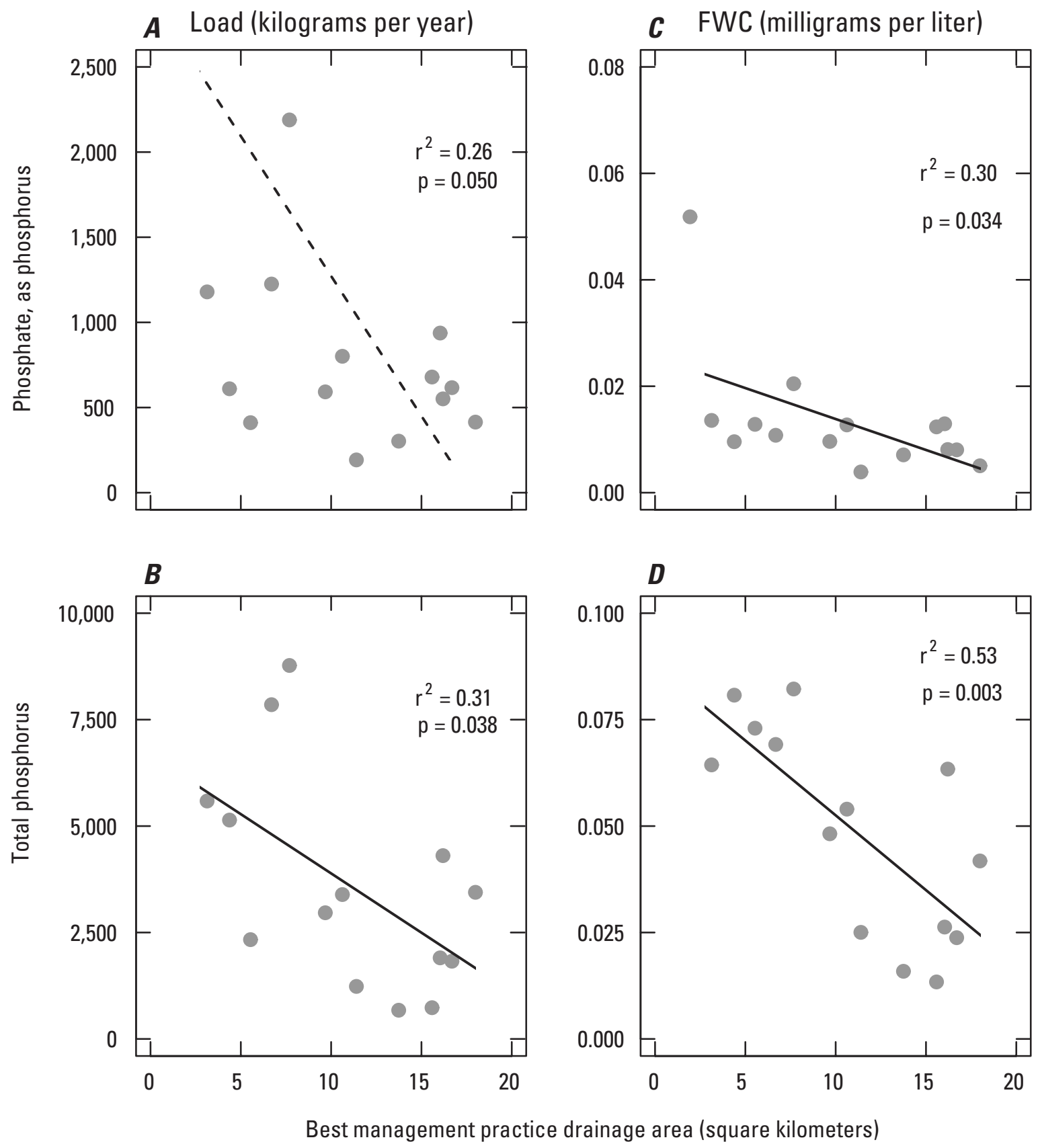

Figure 12. Significant and moderately significant relations of cumulative best management practices (drainage area) to $A$, annual phosphate (as phosphorus) load, $B$, total phosphorus load, $C$, annual phosphate (as phosphorus) flow-weighted concentration, and $D$, annual total phosphorus flow-weighted concentration, Gwynns Falls Carroll Park subwatershed, Maryland, water years 1999-2013. (Dashed line, $0.05<p<0.1$; FWC, flow-weighted concentration) 


\section{Conclusions}

Long-term records of water quality are rare in urban environments, particularly for intermediate size drainage areas like the Gwynns Falls watershed (170.67 square kilometers) in Maryland. Considerable investments are being made in gray and green infrastructures with the expectation of water-quality benefits. There is a critical need for long-term assessment of the effects of these investments. This study, done in cooperation with Blue Water Baltimore, and other studies like it are important steps in understanding the complexity of these changes and can help stakeholders determine whether their investments are resulting in water-quality improvements. Changes in land use and climate, and the multiple sources of data (water-quality constituents and factors affecting these constituents), make these evaluations challenging.

As with other urban areas, the land-cover change was limited in the study subwatersheds as a result of the high proportion of developed land at the start of the study period (1998-2016). Therefore, land-cover change was not considered a factor of influence for water-quality change within the watershed. Precipitation and frequency of runoff producing storms did increase over the study period, particularly in the winter. Increased winter precipitation is an important consideration for area stakeholders because it can exacerbate limitations in gray (for example, wet weather sanitary sewer overflows) and green (for example, reliance on growing season) infrastructure.

In this study, despite the long data record, temporal trends were not apparent for the vast majority of the constituents examined. Despite a high percentage of impervious surface and increasing precipitation, degradation of water quality is not apparent for the most downstream and largest subwatershed (Carroll Park). In fact, improving water quality, determined on the basis of declining phosphate and total phosphorus flow-weighted concentrations, was noted at Carroll Park. The variability in trends throughout the Gwynns Falls watershed highlights the complexity of these systems. Similarly, many of the driving factors that were examined did not have statistically significant relations to the water-quality trends. However, sanitary sewer overflows and best management practices, are factors that appear to affect the water quality at Carroll Park, the most downstream location monitored in the Gwynns Falls watershed. The increasing duration of sanitary sewer overflows was related to increasing loads and concentrations of nutrients; sanitary sewer overflow volume was related to total coliform levels. In contrast, installation of structural best management practices appears to be related to declines in phosphorus. These outcomes, while preliminary, indicate that current efforts and investments in gray and green infrastructure improvements likely positively affect the water quality of the Gwynns Falls watershed. Further, this study has established a framework to evaluate the effect of future gray infrastructure repairs in accordance with the Baltimore City and County Consent Decrees and green infrastructure installation in accordance with the Baltimore City and Baltimore County municipal separate storm sewer system permits and watershed restoration plans.

\section{References Cited}

American Society of Civil Engineers, 2017, 2017 Infrastructure Report Card: American Society of Civil Engineering $112,6 \mathrm{p}$.

Baltimore City Department of Public Works, 2015, MS4 Restoration and TMDL Watershed Implementation Plan, August 19, 2015: Baltimore, Md., Baltimore City Department of Public Works, variously paged.

Bettez, N.D., and Groffman, P.M., 2013, Nitrogen deposition in and near an urban ecosystem: Environmental Science \& Technology, v. 47, p. 6047-6051.

Bettez, N.D., Duncan, J.M., Groffman, P.M., Band, L.E., O’Neil-Dunne, J., Kaushal, S.S., Belt, K.T., and Law, N., 2015, Climate variation overwhelms efforts to reduce nitrogen delivery to coastal waters: Ecosystems, v. 18, p. 1319-1331.

Burgess, K., 2017, Harvesting the value of water: stormwater, green infrastructure, and real estate: Washington, D.C., Urban Land Institute, $72 \mathrm{p}$.

Center for Watershed Protection, 2013, Cost-effectiveness study of urban stormwater BMPs in the James River basin, March 2013: Ellicott City, Md., Center for Watershed Protection, $39 \mathrm{p}$.

Chesapeake Bay Foundation, 2014, Polluted runoff: How investing in pollution control systems improves the Chesapeake Bay region ecology, economy, and health: Annapolis, Md., Chesapeake Bay Foundation, 36 p.

Chiwa, M., Maruno, R., Ide, J., Miyano, T., Higashi, N., and Otsuki, K., 2010, Role of stormflow in reducing N retention in a suburban forested watershed, western Japan: Journal of Geophysical Research-Biogeosciences, v. 115, no. 11, G02004, 11 .

EcoCheck, 2011, Sampling and data analysis protocols for Mid-Atlantic tidal tributary indicators, in Wicks E.C., Andreychek, M.L., Kelsey, R.H., Powell, S.L., eds.: Cambridge, Md., IAN Press, $46 \mathrm{p}$.

ESRI, 2016, ArcGIS Desktop ArcMap: Release 10.5.0: Redlands, Calif., Environmental Systems Research Institute.

Groffman, P.M., Law, N.L., Belt, K.T., Band, L.E., and Fisher, G.T., 2004, Nitrogen fluxes and retention in urban watershed ecosystems: Ecosystems, v. 7, p. 393-403. 
Hayhoe, K., Wake, C.P., Huntington, T.G., Luo, L.F., Schwartz, M.D., Sheffield, J., Wood, E., Anderson, B., Bradbury, J., DeGaetano, A., Troy, T.J., and Wolfe, D., 2007, Past and future changes in climate and hydrological indicators in the U.S. Northeast: Climate Dynamics, v. 28, p. 381-407.

Homer, C., Dewitz, J., Fry, J., Coan, M., Hossain, N., Larson, C., Herold, N., McKerrow, A., VanDriel, J.N., and Wickham, J., 2007, Completion of the 2001 National Land Cover Database for the conterminous United States: Photogrammetric Engineering and Remote Sensing, v. 73, no. 4, p. 337-341.

Homer, C.G., Dewitz, J.A., Yang, L., Jin, S., Danielson, P., Xian, G., Coulston, J., Herold, N.D., Wickham, J.D., and Megown, K., 2015, Completion of the 2011 National Land Cover Database for the conterminous United States-Representing a decade of land cover change information: Photogrammetric Engineering and Remote Sensing, v. 81, no. 5, p. 345-354.

Jantz, P., Goetz, S., and Jantz, C., 2005, Urbanization and the loss of resource land in the Chesapeake Bay Watershed: Environmental Management, v. 36, no. 6, p. 808-825.

Kaushal, S.S., Groffman, P., Band, E.L., Shields, C.A., Morgan, P.R., Palmer, M.A., Belt, K.T., Swan, C.M., Findlay, S., and Fisher, G.T., 2008, Interaction between urbanization and climate variability amplifies watershed nitrate export in Maryland: Environmental Science \& Technology, v. 42, p. 5872-5878.

Kaushal, S.S., Groffman, P.M., Band, L.E., Elliott, E.M., Shields, C.A., and Kendall, C., 2011, Tracking nonpoint source nitrogen pollution in human-impacted watersheds: Environmental Science \& Technology, v. 45, p. 8225-8232.

Kaushal, S.S., and Belt, K.T., 2012, The urban watershed continuum: Evolving spatial and temporal dimensions: Urban Ecosystems, v. 15, p. 409-435.

Kaushal, S.S., Mayer, P.M., Vidon, P.G., Smith, R.M., Pennino, M.J., Newcomer, T.A., Duan, Shuiwang, Welty, C., and Belt, K.T., 2014, Land use and climate variability amplify carbon, nutrient and contaminant pulses: A review with management implications: Journal of the American Water Resources Association, v. 50, no. 3, p. 585-614.

Kaye, J.P., Groffman, P.M., Grimm, N.B., Baker, L.A., and Pouyat, R.V., 2006, A distinct urban biogeochemistry?: Trends in Ecology \& Evolution, v. 21, p. 192-199.

Law, L.N., Band, E.L., and Grove, J.M., 2004, Nitrogen input from residential lawn care practices in suburban watersheds in Baltimore County, MD: Journal of Environmental Planning and Management, v. 4, p. 737-755.
Lawrence, S.J., 2012, Escherichia coli bacteria density in relation to turbidity, streamflow characteristics, and season in the Chattahoochee River near Atlanta, Georgia, October 2000 through September 2008-Description, statistical analysis, and predictive modeling: U.S. Geological Survey Scientific Investigations Report 2012-5037, 81 p. [Also available at http://pubs.usgs.gov/sir/2012/5037/.]

Majcher, E., 2014, Summary report of the urban waters monitoring workshop, 18 June 2014, Draft: Baltimore, Md., Baltimore Urban Waters Partnership, 47 p., accessed January 17, 2018, at https://www.epa.gov/sites/production/files/2015-07/documents/urban-water-monitoringassets_091014.pdf.

Maryland Department of the Environment (MDE), 2010, Patapsco/Back River Watershed SWMM model report: Baltimore, Md., Maryland Department of the Environment [not paged].

Maryland Department of Environment (MDE), 2014, Accounting for stormwater waste load allocations and impervious acres treated - Guidance for NPDES stormwater permits, August 2014: Maryland Department of Environment, 53 p.

Morse, N., and Wollheim, W., 2014, Climate variability masks the impacts of land use change on nutrient export in a suburbanizing watershed: Biogeochemistry, v. 121, p. 45-59.

Moyer, D.L., and Bloomquist, J., 2016, Summary of nitrogen, phosphorus, and suspended-sediment loads and trends measured at the Chesapeake Bay nontidal network stations: Water Year 2014 Update, February 3, 2016, accessed March 1, 2018, at https://cbrim.er.usgs.gov/summary.html, $15 \mathrm{p}$.

Murdock, J., Roelk, D., and Gelwick, F., 2004, Interactions between flow, periphyton, and nutrients in a heavily impacted urban stream: implications for stream restoration effectiveness: Ecological Engineering, v. 22, p. 197-207.

Pelton, T., Bernhardt, C., Burkhart, K., and Lam, S., 2015, Stopping the flood beneath Baltimore's streets: Washington, D.C., Environmental Integrity Project, December 2015, $29 \mathrm{p}$.

R Development Core Team, 2016, R: A Language and Environment for Statistical Computing: Vienna, Austria, R Foundation for Statistical Computing.

Rao, P., Hutyra, L.R., Raciti, S.M., and Templer, P.H., 2014, Atmospheric nitrogen inputs and losses along an urbanization gradient from Boston to Harvard Forest, MA: Biogeochemistry, v. 121, p. 229-245.

Reisinger, A.J., Rosi, E.J., Bechtold, H.A., Doody, T.R., Kaushal, S.S., and Groffman, P.M., 2017, Recovery and resilience of urban stream metabolism following Superstorm Sandy and other floods: Ecosphere, v. 8, p. e01776. 
Sexton, J.O., Song, X-P., Huang, C., Channan, S., Baker, M.E., and Townshend, J.R., 2013, Urban growth of the Washington, D.C.-Baltimore, MD metropolitan region from 1984 to 2010 by annual, Landsat-based estimates of impervious cover: Remote Sensing of Environment, v. 129, p. 42-53.

U.S. Department of Justice and Environmental Protection Agency and Maryland Department of Environment v. City of Baltimore, 2017, Modified Consent Decree, August 2017, 82 p., accessed March 1, 2018, at https://publicworks.baltimorecity.gov/sites/default/files/Modified\%20Consent $\% 20$ Decree.pdf.

U.S. Department of Justice and Environmental Protection Agency and Maryland Department of Environment v. City of Baltimore, 2002, Consent Decree, September 2002, 78 p., accessed March 1, 2018, at https://www.epa.gov/sites/production/files/2013-09/documents/baltimore-cd.pdf.

U.S. Department of Justice and Environmental Protection Agency and Maryland Department of Environment v. Baltimore County, 2005, Consent Decree, September 2005, 115 p., accessed March 1, 2018, at https://www. epa.gov/sites/production/files/2013-09/documents/baltimoreco072605-cd.pdf.

U.S. Environmental Protection Agency (EPA), 2010, Chesapeake Bay total maximum daily load for nitrogen, phosphorus, and sediment, December 2010: U.S. Environmental Protection Agency, Region 3, 93 p.

U.S. Environmental Protection Agency (EPA), 2017, What is green infrastructure?: U.S. Environmental Protection Agency, accessed March 1, 2018, at https:/www.epa.gov/ green-infrastructure/what-green-infrastructure.

Valiela, I., Collins, G., Kremer, J., Lajtha, K., Geist, M., Seely, B., Brawley, J., and Sham, C.H., 1997, Nitrogen loading from coastal watersheds to receiving estuaries: New method and application: Ecological Applications, v. 7, p. 358-380.
Vietz, G.J., Walsh, C.J., and Fletcher, T.D., 2016, Urban hydrogeomorphology and the urban stream syndrome: treating the symptoms and causes of geomorphic change: Progress in Physical Geography, v. 40, p. 480-492.

Walsh, C.J., Roy, A.H., Feminella, J.W., Cottingham, P.D., Groffman, P.M., and Morgan, R.P., 2005, The urban stream syndrome: current knowledge and the search for a cure: Journal of the North American Benthological Society, v. 24, p. 706-723.

Walsh, J., Wuebbles, D., Hayhoe, K., Kossin, J., Kunkel, K., Stephens, G., Thorne, P., Vose, R., Wehner, M., Willis, J., Anderson, D., Doney, S., Feely, R., Hennon, P., Kharin, V., Knutson, T., Landerer, F., Lenton, T., Kennedy, J., and Somervill, R., 2014, Ch. 2, Our changing climate, in Melillo, J.M., Terese, T.C., and Yohe, G.W., eds. Climate change impacts in the United States: The Third National Climate Assessment: Washington, D.C., U.S. Global Change Research Program, p. 19-67.

Waterfront Partnership, 2014, Healthy Harbor Report Card: Waterfront Partnership, accessed January 27, 2018, at http://baltimorewaterfront.com/healthy-harbor/report-card/.

Waterfront Partnership, 2013, Healthy Harbor Report Card: Baltimore, Md., Waterfront Partnership.

Waterfront Partnership, 2012, Healthy Harbor Report Card: Baltimore, Md., Waterfront Partnership.

Wollheim, W.M., Green, M.B., Pellerin, B.A., Morse, N.B., and Hopkinson, C.S., 2013, Causes and consequences of ecosystem service regionalization in a coastal suburban watershed: Estuaries and Coasts, v. 38, p. 19-34.

Woytowitz, E.L., Majcher, E.H., and Reisinger, A.J., 2018, Nutrient, bacteria, ammonia, total Kjeldahl nitrogen, total suspended solids annual loads; green and gray infrastructure; land cover change; and climate data in the Gwynns Falls subwatersheds, Baltimore, Maryland, 1998-2016: U.S. Geological Survey data release, https://doi. org/10.5066/F76T0KTJ. 

For more information, contact:

Director, MD-DE-DC Water Science Center

U.S. Geological Survey

5522 Research Park Drive

Baltimore, MD 21228

or visit our website at:

http://md.water.usgs.gov/

Publishing support provided by the West Trenton and Pembroke Publishing Service Centers 


\section{$\frac{\mathbb{2}}{3}$}

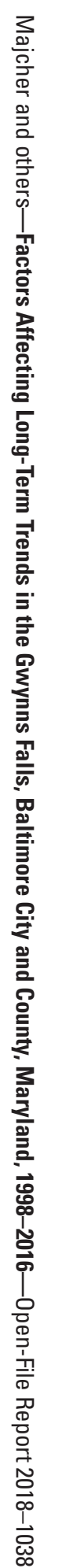

6 Printed on recycled paper 